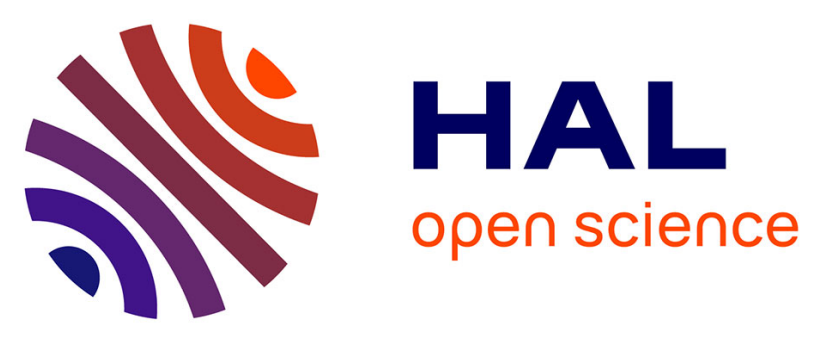

\title{
Re-evaluation of Leonian and Liberian events in the geodynamical evolution of the Man-Leo Shield (West African Craton)
}

Gnagnon Raymond-Stéphane Koffi, Alain Nicaise Kouamelan, Marc Ephrem Allialy, Yacouba M. Coulibaly, Jean-Jacques Peucat

\section{To cite this version:}

Gnagnon Raymond-Stéphane Koffi, Alain Nicaise Kouamelan, Marc Ephrem Allialy, Yacouba M. Coulibaly, Jean-Jacques Peucat. Re-evaluation of Leonian and Liberian events in the geodynamical evolution of the Man-Leo Shield (West African Craton). Precambrian Research, 2020, 338, pp.105582. 10.1016/j.precamres.2019.105582 . insu-02417226

\section{HAL Id: insu-02417226 https://hal-insu.archives-ouvertes.fr/insu-02417226}

Submitted on 18 Dec 2019

HAL is a multi-disciplinary open access archive for the deposit and dissemination of scientific research documents, whether they are published or not. The documents may come from teaching and research institutions in France or abroad, or from public or private research centers.
L'archive ouverte pluridisciplinaire HAL, est destinée au dépôt et à la diffusion de documents scientifiques de niveau recherche, publiés ou non, émanant des établissements d'enseignement et de recherche français ou étrangers, des laboratoires publics ou privés. 


\section{Journal Pre-proofs}

Re-evaluation of Leonian and Liberian events in the geodynamical evolution of the Man-Leo Shield (West African Craton)

Gnagnon Raymond-Stéphane Koffi, Alain Nicaise Kouamelan, Marc Ephrem Allialy, Yacouba Coulibaly, Jean-Jacques Peucat

PII: S0301-9268(19)30104-4

DOI: https://doi.org/10.1016/j.precamres.2019.105582

Reference: PRECAM 105582

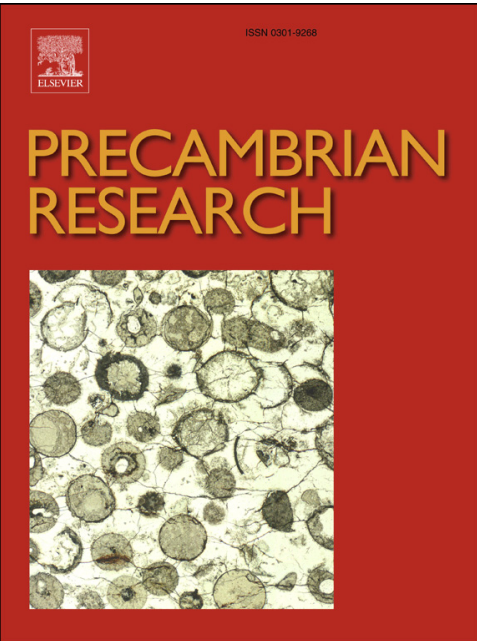

To appear in:

Precambrian Research

Received Date:

19 February 2019

Revised Date:

10 December 2019

Accepted Date:

14 December 2019

Please cite this article as: G. Raymond-Stéphane Koffi, A. Nicaise Kouamelan, M. Ephrem Allialy, Y. Coulibaly, J-J. Peucat, Re-evaluation of Leonian and Liberian events in the geodynamical evolution of the Man-Leo Shield (West African Craton), Precambrian Research (2019), doi: https://doi.org/10.1016/j.precamres.2019.105582

This is a PDF file of an article that has undergone enhancements after acceptance, such as the addition of a cover page and metadata, and formatting for readability, but it is not yet the definitive version of record. This version will undergo additional copyediting, typesetting and review before it is published in its final form, but we are providing this version to give early visibility of the article. Please note that, during the production process, errors may be discovered which could affect the content, and all legal disclaimers that apply to the journal pertain.

(C) 2019 Published by Elsevier B.V. 
Re-evaluation of Leonian and Liberian events in the geodynamical evolution of the Man-Leo Shield (West African Craton)

Gnagnon Raymond-Stéphane KOFFla*, Alain Nicaise KOUAMELANa, Marc Ephrem ALLIALYa, Yacouba COULIBALYa, Jean-Jacques PEUCAT ${ }^{\text {b }}$

aUFR-STRM Université F.H.B. Cocody-Abidjan, 22 B.P. 582 Abidjan 22, Côte d'Ivoire

b Géosciences Rennes, UMR CNRS 6118, Université de Rennes I, 35042 Rennes

CEDEX, France

${ }^{*}$ Corresponding author at: UFR-STRM Université F.H.B. Abidjan-Cocody, 22 B.P.

582 Abidjan 22, Côte d'Ivoire, E-mail address: koffignagnon@gmail.com ; phone:

$+22558043409$ 


\section{Abstract}

The Leonian (3400-3100 Ma) and Liberian (2850-2700 Ma) events are important magmatic and tectono-metamorphic events in the Archean domain of the Man-Leo Shield in the southern West Africa Craton. The older Leonian event was associated with crust formation, which was variably reworked during the younger Liberian event. In the Man domain of western Côte d'Ivoire, zircon in-situ dating by LA-ICPMS of Granulitic Grey Gneisses (GGGs), the Mangouin charnockite and the Lagoulalé augen orthogneiss allows for the re-evaluation of magmatic and metamorphic activity related to the Leonian and Liberian events. We report here our findings that the GGGs represent the oldest rocks in the study area and formed during the Leonian event. The ages recorded in the GGGs in the Man area are $3156 \pm 24,3098 \pm 19$, $3093 \pm 49$ and $3019 \pm 53 \mathrm{Ma}$. The ages of $3156 \pm 24$ and $3098 \pm 19$ Ma represent Leonian juvenile magmatism while those of $3093 \pm 49$ and $3019 \pm 53$ Ma represent Leonian metamorphism. The ages of the Mangouin charnockite and the Lagoulalé augen orthogneiss are $2798 \pm 8 \mathrm{Ma}$ and $2795 \pm 9 \mathrm{Ma}$, respectively, and are interpreted to record peak metamorphic conditions during the Liberian event. Zircon from the augen orthogneiss includes an inherited core with an age of $3121 \pm 37 \mathrm{Ma}$, which corresponds to Leonian GGG ages. This inheritance indicates that the Mangouin charnockite and the Lagoulalé augen orthogneiss were derived either partially or completely from Leonian formations. A previously constrained Sm-Nd model age of $3250 \mathrm{Ma}$ for the charnockite and augen orthogneiss agrees with such a process. The majority of Th/U is higher, indicating a magmatic origin for most zircons. The Leonian and Liberian events are proposed as two distinct events in Man-Leo Shield.

Keywords: Leonian; Liberian; Birimian; tectono-metamorphic event; reworking. 


\section{Introduction}

The Archean Eon represents nearly half of Earth's history, and lasted between 4.0 to $2.5 \mathrm{Ga}$. It has previously been proposed that more than 50 to $75 \%$ of the continental crust differentiated from the mantle during this period (Nelson and Depaolo, 1985; Taylor and McLennan, 1985, Rudnick, 1995: Belousova et al. 2010; Dhuime et al., 2012). However, recent studies support a smaller amount of crustal production, particularly during the Hadean (Fisher and Vervoort, 2018). It is further established that geothermal gradients were also higher in the Archean (Mareschal and Jaupart, 2006). This makes the Archean a particularly interesting period of Earth's history, in terms of petrology and tectonics as well as mineralization. At the petrological level, grey gneisses are a typical Archean lithology, of which TTG orthogneiss suites are a common component that has been the focus of extensive research (Black et al., 1971; Goldich et al., 1970; Hanson et al., 1971; Heimlich and Banks, 1968; Kouvo and Tilton, 1966; Moorbath, 1975; Moorbath et al., 1972, Savanier et al., 2003: Martin et al., 2014).

In the southern West African Craton (WAC), TTGs have been dated to between 3.6 and 3.0 Ga (e.g. Camil, 1984; Potrel et al., 1996; Kouamelan et al., 1997a, 1997b; Thiéblemont et al., 2001; Kouamelan et al., 2015; De Waele et al., 2015; Rollinson, 2016) and inherited zircons are known from 3.7 Ga (Barth et al., 2002; Gouedji et al., 2014; Eglinger et al., 2017). In Côte d'Ivoire, grey gneisses have been dated between 3.2 and $3.0 \mathrm{Ga}$, and their trace element composition shows TTG characteristics (Kouamelan, 1996; Kouamelan, 1997a, Kouamelan et al., 2015).

In the Archean of the southern West African Craton, two events are recognized based on the "classic" subdivision of e.g. Cahen et al. (1984). The first is the Leonian 
$(\sim 3.0 \mathrm{Ga})$ and the second is the Liberian $(\sim 2.8 \mathrm{Ga})$. Furthermore, Camil (1984), Kouamelan (1996) and Kouamelan et al. (1997a) highlighted petrological and geochronological differences between these events in the Man domain. The Leonian (is characterized by banded granulite facies grey gneisses with some metre-thick sheets of Opx-bearing pink granitic granulite (Camil, 1984). The Liberian is characterized by supracrustal rocks in granulite facies. However, De Waele et al. (2015) recently proposed a revision of these two terms based on published age data, where the Leonian refer to early crustal nucleation between ca. 3.5-3.4 Ga, and the Liberian to continuous activity between $3.05-2.65 \mathrm{Ga}$.

This study presents new geochronological data on granulitic grey gneisses (GGGs), charnockites, and granodiorites from the Man region in western Côte d'Ivoire obtained by in-situ analysis of zircon using Laser-Ablation Inductively-CoupledPlasma Mass-Spectrometry (LA-ICP-MS). The new data is an improvement upon previous ages obtained from the Man region. These were based on direct evaporation methodologies (Kouamelan et al., 1997a), which can give erroneous results due to partial lead loss or inherited cores, particularly in complex zircon grains. Considering the results obtained in this study, the events in the Man domain are distinguish and a geodynamic model for the evolution of the West African Craton from the Archean to the Paleoproterozoic (Birimian) is discussed.

\section{Geological setting}

The West African Craton consists of Precambrian formations bordered by mobile belts and sedimentary basins (Fig. 1, Bessoles, 1977; Abouchami et al., 1990; Kouamelan et al., 1997; Egal et al., 2002; Persits et al., 2002; Peucat et al., 2005; Ennih and Liégeois, 2008; Pitra et al., 2010; Baratoux et al., 2011; Schofield et al., 
2012; Berger et al., 2013). The basement of the West African Craton is exposed in two shields: the Reguibat Shield in the north and the Man-Leo Shield in the south. Both shields are made up of an Archean and a Paleoproterozoic domain. Previous geochronological studies have identified two major magmatic and tectonometamorphic events in Archean rocks of the Man-Leo Shield (MacFarlane et al., 1980; Beckinsale et al., 1980; Rollinson and Cliff, 1982; Egal et al., 2002; Bessoles 1977; Cahen et al., 1984; Rollinson 2016). The first event is the Leonian, which was defined in Sierra Leone by McFarlane et al. (1980). Radiometric ages (Pb-Pb, U-Pb and $\mathrm{Rb}-\mathrm{Sr}$ ) place this event between ca. $3.3 \mathrm{Ga}$ and $3.0 \mathrm{Ga}$ (Eberhardt et al., 1962; Beckinsale et al., 1980; Camil, 1984; Thiéblemont et al., 2004). The second event is the Liberian (ca. 2.9-2.7 Ga), which is the most significant metamorphic and magmatic event in the Archean domain of the Man-Leo Shield. The Paleoproterozoic domain $(2.27-1.98 \mathrm{Ga})$ consists of crust formed during the Eburnean megacycle (Tagini, 1971; Bonhomme, 1962; Yacé, 1984; Tempier, 1986; Lemoine, 1988; Sylvester and Attoh, 1992; Feybesse and Milési, 1994; Vidal and Alric, 1994; AmaSalah et al., 1996; Hirdes and Davis, 2002; Pouclet et al., 2006; Feybesse et al., 2006; Baratoux et al., 2011; De Kock et al., 2012; Parra-Avilla et al., 2016; Grenholm et al., 2019).

The Archean domain of Côte d'Ivoire is located to the west of the Sassandra Fault, which separates it from Paleoproterozoic crust to the east (Fig. 2). Leonian units in Côte d'Ivoire are characterized by grey orthogneiss, pink granulite, anatectic metapelite, and ferriferous quartzites (Camil, 1984). The Leonian formations were reworked during Liberian tectono-metamorphic activity (Kouamelan et al., 1997a), which was associated with high-grade metamorphism, deformation, magmatism, and 
deposition of supracrustal formations (Beckinsale et al., 1980; MacFarlane et al., 1980; Rollinson and Cliff, 1982; Egal et al., 2002; Rollinson 2016).

Our study area is located in the Man domain, to the west of the Sassandra Fault (Fig. 2). The Man domain, in the narrowest sense, could be limited to the area between parallels $6^{\circ} \mathrm{N}$ and $8^{\circ} \mathrm{N}$ and is divided into two domains by the Man-Danané fault. The northern domain is mainly composed of tonalitic grey gneiss, while the southern domain can be subdivided into three sub-domains (Kouamelan et al., 1997a; Kouamelan et al., 2018). These are composed of:

- An intermediate unit (the Danané-Kouibli domain) mainly containing orthopyroxene-bearing migmatitic gneiss.

- $\quad$ The Logoualé band of biotite-bearing migmatitic gneiss and charnockitic gneiss.

- The Toulepleu-Ity unit consisting of metasediments, metavolcanites and granitoids.

\section{Methods}

We have applied a classic mineral separation procedure to concentrate minerals suitable for $\mathrm{U}-\mathrm{Th}-\mathrm{Pb}$ dating using the facilities available at Geosciences Rennes. Rocks were crushed and only the powder fraction with a diameter of $<250 \mu \mathrm{m}$ was kept. Heavy minerals were concentrated in succession by Wilfley table and heavy liquids. Magnetic minerals were then removed with an isodynamic Frantz separator. Zircon grains were carefully handpicked under a binocular microscope and embedded in epoxy mounts. The grains were then hand-grounded and polished on a lap wheel with a $6 \mu \mathrm{m}$ and $1 \mu \mathrm{m}$ diamond suspension successively. The sorted zircon grains are mounted on resin studs. Furthermore, subsequent grinding and polishing 
exposed the cores of all grains. Optical images of zircons show that they are homogeneous and often oscillatory. Essentially the cores of the zircon grains have been analyzed to have the oldest ages. U-Th-Pb geochronology of zircon was conducted with in-situ Laser-Ablation Inductively-Coupled-Plasma MassSpectrometry (LA-ICPMS) at Geosciences Rennes using a ESI NWR193UC excimer laser coupled to a quadrupole Agilent 7700x ICP-MS equipped with a dual pumping system to enhance sensitivity. The instrumental conditions are reported in Table 1. Concordia diagrams and weighted mean calculations were made using Isoplot 4.0 with 2 б-error and 95\% confidence levels (Ludwig, 2008).

\section{Sample descriptions}

\subsection{Granulitic grey gneisses}

The granulite grey gneiss samples (GGGs) studied here are labeled YAL-1 and TON1. Petrographic descriptions of these rocks are summarized in Table 2 and presented in detail in Kouamelan 1996; Kouamelan et al., 1997. Two main morphologies can be distinguished among the zircons of the GGGs. There are (i) elongated grains with generally blunt tips and (ii) round grains with multiple facets. Elongated zircons have a magmatic zoning and sometimes a core. They have a very irregular surface. Shallow cavities can be observed along the grain margins. The absence of faces could be the result of the extreme conditions imposed during granulite metamorphism. Round zircons generally do not have a core though magmatic zoning can still be observed (Kouamelan, 1996).

\subsection{Augen orthogneiss and the charnockite}

The main features of these rocks are summarized in Table 2. Zircons of the augen orthogneiss and the charnockite have comparable morphologies. They are elongated 
and euhedral with rounded tips and generally $>150 \mu \mathrm{m}$. They correspond to the high-temperature S24/25 zircon types according to the Pupin (1980) classification; no cores have been observed.

\section{Results}

\subsection{YAL-1: grey granulitic orthogneiss}

Twenty-two zircons spots were analyzed and can be divided into three groups based on ${ }^{207} \mathrm{~Pb} /{ }^{206} \mathrm{~Pb}$ (Table 3). In group 1 , seven concordant spots yield an average ${ }^{207} \mathrm{~Pb} /{ }^{206} \mathrm{~Pb}$ ages of $3098 \pm 19 \mathrm{Ma}(\mathrm{MSWD}=0.27 ; \mathrm{n}=7)$. In group 2 , one concordant spot gives a ${ }^{207} \mathrm{~Pb} /{ }^{206} \mathrm{~Pb}$ date of $3019 \pm 53 \mathrm{Ma}$ (Fig. 3). The first age is interpreted to correspond to magmatic crystallization while the second would represent partial $\mathrm{Pb}-$ loss or metamorphism during the Leonian event. In group 3, six zircon spots yield younger ${ }^{207} \mathrm{~Pb} /{ }^{206} \mathrm{~Pb}$ ages of ca. $2814-2791 \mathrm{Ma}$ and define an upper intercept age of $2812 \pm 14 \mathrm{Ma}(\mathrm{MSWD}=0.91 ; \mathrm{n}=6$, Fig. 3). This age is interpreted to represent metamorphic overprinting at ca. $2.8 \mathrm{Ga}$ associated with the Liberian event. The zircon spots of this group also define a lower intercept age of $189 \pm 308 \mathrm{Ma}$ (Fig. 3). We attribute this lower intercept to thermal disturbance linked to mafic CAMP magmatism (e.g. Deckart et al., 2005; Whalen et al., 2015). These zircons show considerable variation in both Th and $U$ concentrations and yield Th/U of $0.14-0.98$.

\subsection{TON-1: grey granulitic orthogneiss}

Sixteen zircon grains were analyzed and three $\mathrm{U}-\mathrm{Pb}$ age groups are defined based on ${ }^{207} \mathrm{~Pb} /{ }^{206} \mathrm{~Pb}$ (Table 3). In group 1, four concordant spots give an average of ${ }^{207} \mathrm{~Pb} /{ }^{206} \mathrm{~Pb}$ ages of $3156 \pm 24 \mathrm{Ma}(\mathrm{MSWD}=0.73 ; \mathrm{n}=4)$. In group 2, one concordant spot gives a ${ }^{207} \mathrm{~Pb} /{ }^{206} \mathrm{~Pb}$ ages of $3093 \pm 49 \mathrm{Ma}$ (Fig. 4). Like in sample YAL-1, the first age is interpreted to correspond to the magmatic crystallization of this rock and the 
second represent an event of partial Pb-loss or metamorphism during the Leonian. In group 3, two zircon grains yield younger concordant ${ }^{207} \mathrm{~Pb} /{ }^{206} \mathrm{~Pb}$ ages between 2825 $2805 \mathrm{Ma}$, which define an average ${ }^{207} \mathrm{~Pb} /{ }^{206} \mathrm{~Pb}$ ages of $2806 \pm 25 \mathrm{Ma}(\mathrm{MSWD}=0.25$; $\mathrm{n}=2$, Fig. 4). The age defined by group 3 zircon grains is interpreted to record metamorphic overprinting during the Liberian event. The analyzed zircons mostly preserve magmatic oscillatory zoning and commonly exhibit high Th/U from 0.14 to 0.98 , excluding spots 9,16 and $25(0.05,0.09$ and 0.09 respectively).

\subsection{MANG-1: charnockite}

Twenty-six spots on twenty-four zircon grains from charnockite rock sample MANG-1 (Table 3) were analyzed. The twenty-six concordant spots (>95\%) define an average ${ }^{207} \mathrm{~Pb} /{ }^{206} \mathrm{~Pb}$ ages of $2798 \pm 8 \mathrm{Ma}(\mathrm{MSWD}=0.59 ; \mathrm{n}=26$, Fig. 5 ). It is interpreted to represent the crystallization age of the charnockite. The analyzed zircon domains are characterized by high Th/U (0.32-1.07).

\subsection{LAG-1: augen orthogneiss}

Twenty-two spots on twenty zircon grains of the augen orthogneiss sample LAG-1 (Table 3) were analyzed. All concordant spots (>95\%) with near-absent lead-loss define an average ${ }^{207} \mathrm{~Pb} / 206 \mathrm{~Pb}$ ages of $2795 \pm 9 \mathrm{Ma}(\mathrm{MSWD}=1.01 ; \mathrm{n}=22$, Fig. 6). This age is taken to represent the crystallization age of this rock. One zircon (spot 18) yields an older ${ }^{207} \mathrm{~Pb} / 206 \mathrm{~Pb}$ date of ca. $3121 \mathrm{Ma}$, suggesting inheritance. All analyzed zircon domains have $T h / U>0.1$, which are typical for magmatic zircon (Williams and Claesson, 1987), excluding spot 34 (0.08).

\section{Discussion}

\subsection{The Leonian event: juvenile magmatism}


The ages obtained in this study (Table 3 ) are consistent with those reported by Camil (1984) and Kouamelan et al. (1997a) from the same area, using the TIMS method on zircon populations and single-zircon evaporation, respectively. The ages of $3156 \pm 24$, $3098 \pm 19,3093 \pm 49$, and $3019 \pm 53$ Ma for the granulitic grey gneisses (GGGs) are Leonian and represent the oldest ages in our study area. These data indicate a period of magmatic activity between ca. $3160-3100 \mathrm{Ma}$, followed by Leonian metamorphism between ca. 3100-3000 Ma. The ages recorded by the GGGs at $2812 \pm 14$ and $2806 \pm 25$ Ma record the effect of Liberian metamorphism. In the Man domain, these rocks have whole-rock Nd model ages between 3.3 and $3.2 \mathrm{Ga}$ (Kouamelan et al., 1997a). We suggest that the Leonian event was dominated by juvenile magmatism with limited crustal recycling. Rollinson (2016) in his synthesis of Archean geology in Sierra Leone, Liberia, Guinea, and Côte d'Ivoire highlights rocks formed at 3.26-3.05 Ga. Leonian event is thereby present throughout the WAC.

\subsection{The Liberian event: reworking of Leonian crustal components}

The Manguoin charnockite dated at ca. $2798 \mathrm{Ma}$ and the Lagoulalé augen orthogneiss of ca. 2794 Ma have coeval ages and may have formed during peak metamorphism during the Liberian event. The end of this tectono-metamorphic event occurred around $2740 \mathrm{Ma}$, which corresponds to the whole rock-garnet Sm-Nd age of a granulitic pink granite sampled in same area (Kouamelan et al., 1997a). The Manguoin charnockite and the Lagoulalé augen orthogneiss have previously constrained whole-rock Nd model ages of about $3250 \mathrm{Ma}$ (Kouamelan, 1996), which

predates their emplacement ages by ca. 450 Ma. This implies that the Manguoin charnockite and Lagoulalé augen orthogneiss were sourced from older Mesoarchean crust. This is also supported by the inherited zircon in the augen orthogneiss of LAG1 , which records a ${ }^{207} \mathrm{~Pb} / 206 \mathrm{~Pb}$ age of $3121 \pm 37 \mathrm{Ma}$. This inherited age is a minimum 
and approximately $100 \mathrm{Ma}$ younger than the $\mathrm{Nd}$ model age. Moreover, this inherited age corresponds to the age of the GGGs. In view of the above, it can be ascertained that the Liberian formations have Leonian protoliths. The latter are most certainly juvenile lithological assemblages given the small age difference with the $\mathrm{Nd}$ model age. In the Reguibat Shield, Potrel et al. (1998) reported ages of charnockitic granite ranging between 2.9-2.7 Ga with $\mathrm{Nd}$ model ages between 3.2-3.1 Ga. These rocks have positive $\varepsilon N d(3.0)$, in agreement with a juvenile origin for Leonian rocks. Thus, the Liberian event succeeded the Leonian event, and was associated with significant crustal reworking. The presence of granulite sheets within the GGGs, particularly in the TON-1 rock, shows that they were subjected to high-grade metamorphism (Kouamelan et al., 1997a; Kouamelan, 1996).

The data indicate that distinct magmatic events occurred during Leonian (3.3-3.0 $\mathrm{Ga})$ and Liberian $(2.8-2.7 \mathrm{Ga})$ times. These same events are recognized across the Archean domain in the Man-Leo Shield, including in eastern Guinea (Bering et al., 1998; Thiéblemont et al., 2004), Liberia (Hurley et al., 1971), and Sierra Leone (Barth et al., 2002). They are also recorded in the Reguibat Shield in the northern West African Craton (Fig. 1, Potrel et al., 1996, 1998; Schofield et al., 2012; Montero et al., 2014). This indicates that the Leonian and Liberian were regionally significant events. Our data contradict De Waele et al. (2015) who proposed a revision of the terms Leonian and Liberian, with the Leonian referring to Paleoarchean crustal nucleation between 3.55-3.40 Ga, while the Liberian represent continuous crustal growth between ca. 3.05-2.6 Ga. The presence of inherited zircons in the younger suite and their $\mathrm{Nd}$ model age ranging to $3.4-3.3 \mathrm{Ga}$ indicate reworking of the older gneisses (Rollinson, 2016). At present time, there is no knwon juvenile magmatism at 2.7-2.8 
Ga. Although Paleoarchean ages have not been found yet in the Man Shield of Côte d'Ivoire, we argue that the Leonian and Liberian are two distinctive events.

\subsection{Leonian and Liberian events in the geodynamical evolution of the Man}

\section{Shield}

The oldest ages recorded in the WAC range from 3.7-3.5 Ga and are scarce. These are mostly inherited ages (Barth et al., 2002; Gouédji et al., 2014; Eglinger et al., 2017; Asiedu et al., 2017; Parra-Avilla et al., 2017; Petersson et al., 2016; 2017, 2018), except for the scarce crustal segments present in the Mauritanian part of the Reguibat Shield (Potrel et al., 1996) and in the Guinean part of the Man-Leo Shield (Thiéblemont et al., 2001). In Sierra Leone, Barth et al. (2002) reported an age of $3.44 \mathrm{Ga}(\mathrm{Re}-\mathrm{Os}$ on whole rock) on rocks that the authors described as eclogite. The formations frequently encountered in the Man domain and elsewhere in the Archean of the WAC are the granulitic grey gneisses (GGGs) and paragneisses like kinzigite. The latter are often associated with magnetite bearing quartzites and amphibolepyroxenites. GGGs are therefore the oldest rocks in the WAC after the rare relics highlighted by Potrel et al. (1996) and Thiéblemont et al. (2001). Based on the results obtained in this work and considering the Nd model ages of the GGGs (Kouamelan et al., 1997a), the Leonian event can be considered as occurring in the range of ca. 3.4 to $3.1 \mathrm{Ga}$. Most of the ages obtained on the gneissic formations in the Man-Leo and Reguibat Shields actually belong to this range (Kouamelan et al., 1997a; Potrel et al., 1998; Barth et al., 2002; Thiéblemont et al., 2004). However, we would assign the older ages $(3.7-3.4 \mathrm{Ga})$ to pre-Leonian phase. This age range of $300 \mathrm{Ma}$ could demonstrate the existence of many small continental crustal blocks that evolved separately during this period. We consider the younger ages in the Leonian rocks between 3.1 and $3.0 \mathrm{Ga}$ to be mainly due to metamorphism, because they are few 
and in the samples YAL-1 and TON-1 of this study overprint the older ages. The characteristics of these metamorphic and/or tectonic episodes need to be demonstrated in subsequent work, and to what extent they were responsible for the deformation of Leonian formations.

After the Leonian, the Liberian event is the major tectono-metamorphic and magmatic event in the Archean domain of the WAC. As opposed to Leonian formations which are systematically gneissic, the Liberian formations can be undeformed such as the Mangouin charnockite or the Yorogue granodiorite, or weakly deformed such as the Lagoualé augen orthogneiss (Table 2; Camil, 1984; Kouamelan, 1996). The ages of the Liberian formations in Côte d'Ivoire are grouped in a smaller range $(2.8-2.7 \mathrm{Ga})$, compared to that of the Leonian formations. An important characteristic of the Liberian formations is that they are sourced from Leonian crust. This is supported by their negative $\varepsilon_{\mathrm{Nd}}$ at $2.8 \mathrm{Ga}$ and $\mathrm{Nd}$ model ages ranging between 3.3 and 3.1 Ga (Kouamelan et al., 1997a; Potrel et al., 1998). The presence of inherited zircon with Leonian ages highlighted in this study corroborates the crustal signature of the Liberian rocks. The second characteristic is that the dating of the different facies of the Liberian rocks allows to constrain the high-grade and retrograde phase of this metamorphic event. Thus, the Mangouin charnockite dated at $2798 \pm 8 \mathrm{Ma}$ characterizes the paroxysm of Liberian metamorphism (Kouamelan et al. 1997a), while Touijenjert granites $(2726 \pm 7 \mathrm{Ma})$ in the Reguibat Shield (Potrel et al., 1998) characterizes the retrograde phase. However, the temporal difference between the Mangouin and Touijenjert intrusions may also be a reflection of diachronous processes, where metamorphism and magmatism occurred at different times across the Archean crust. 
In terms of geodynamics, we propose that the Liberian event represents a collisional phase between Leonian crustal blocks. The Liberian magmatism that followed was highly contaminated by the Leonian crust. This model makes it possible to clearly distinguish between the Leonian and Liberian events that we highlight in the Man domain. The Archean continent was subsequently affected by the tectonic and magmatic events that were associated with the Birimian crust (Kouamelan et al., 1997a, Thiéblemont et al., 2004). The age of $180 \pm 380$ Ma defined by the lower intercept of sample YAL-1 is close to the age of the ca. 200 Ma CAMP magmatism associated with the opening of the Atlantic Ocean, which also affected the crust in the Kenema-Man craton (e.g. Deckart et al., 2005; Whalen et al., 2015).

\section{Conclusions}

LA-ICP-MS in-situ U-Pb dating has been performed on zircons from the granulitic grey gneiss $(3.15-3.01 \mathrm{Ga})$, the Mangouin charnockite and the Lagoulalé augen orthogneiss $(2.8 \mathrm{Ga})$ located in the Archean domain of western Côte d'Ivoire. This has allowed for the reassessment of the Leonian and Liberian events in the geodynamic evolution of the West African Craton. GGGs crystallized during the Leonian event, which corresponds to juvenile magmatism with subsequent metamorphism over a period of 300 million years (3.4-3.1 Ga). The GGGs represent the oldest rocks in the Man domain. The Mangouin charnockite and the Lagoulalé augen orthogneiss formed during the Liberian tectono-metamorphic and magmatic event $(2.85-2.7 \mathrm{Ga})$. Liberian magmatism corresponds to the reworking of Leonian juvenile units. These Leonian juvenile units collided during the Liberian event. Liberian magmatism was strongly contaminated by the Leonian crust. The Leonian and Liberian events are distinct events in the Man-Leo Shield. 


\section{Acknowledgements}

The authors are very grateful to C. Delor (BRGM), Y. Simeon (ANTEA-Orleans), Pr J. Camil (SODEMI) and Dr. B.D. Yao (Direction de la Géologie-Abidjan) for their material and financial support through the French FAC II project involving the Direction de la Géologie (Côte d'Ivoire) and the BRGM (France). We are also grateful to J-L. Paquette and M. Poujol for their help in geochronological data acquisition. The manuscript was substantially improved by constructive comments from three reviewers: G.S. de Kock, M. Grenholm and A. Petersson and proofreading of Ph. Rodenbough. Finally, the editorial handling of the journal editors, Prof. W. Teixeira is deeply appreciated.

\section{References}

Abouchami, W., Boher, M., Michard A., Albarede, F., 1990. A major 2.1 Ga old event of mafic magmatism in West Africa: An early stage of crustal accretion. Journal Geophysical Research Letter 95, 17605-17629.

Ama-Salah, I., Liegeois, J.P. and Pouclet, A., 1996. Evolution d'un arc insulaire océanique birimien précoce au Liptako nigérien (Sirba): géologie, géochronologie et géochimie. Journal of African Earth Sciences 22, 235-254.

Asiedu, D.K., Asong, S, Atta-Peters D., Sakyi P.A., Dampare S.B., Anani C.Y., BenXun S., 2017. Geochemical and Nd-isotopic compositions of juvenile-type Paleoproterozoic Birimian sedimentary rocks from southeastern West African Craton (Ghana): Constraints on provenance and tectonic setting. Precambrian Research 300, 40-52. 
Baratoux, L., Metelka, V., Naba, S., Jessell, M.W., Grégoire, M., Ganne, J., 2011. Juvenile Paleoproterozoic crust evolution during the Eburnean orogeny (2.2$2.0 \mathrm{Ga}$ ), western Burkina Faso. Precambrian Research 191, 18-45.

Barth, M.G., Rudnick, R.L., Carlson R.W. Horn I. McDonough W. F., 2002. Re-Os and $\mathrm{U}-\mathrm{Pb}$ geochronological constraints on the eclogite-tonalite connection in the Archaean Man Shield, West Africa. Precambrian Research 118, 267-283.

Beckinsale, R.D., Gale, N.H., Pankhurst, R.J., Macfarlane, A., Crow, M.J., Arthurs, J.W., Wilkinson, A.F., 1980. Discordant $\mathrm{Rb}-\mathrm{Sr}$ and $\mathrm{Pb}-\mathrm{Pb}$ whole rock isochron for the Archaean basement of Sierra Leone. Precambrian Research 13,6376.

Belousova, E. A., Kostitsyn, Y. A., Griffin, W. L., Begg, G. C., O’Reilly, S. Y., Pearson, N. J. 2010., The growth of the continental crust: Constraints from zircon Hf-isotope data. Lithos, 119, 457-466. doi:10.1016/j.lithos.2010.07.024.

Berger, J., Diot, H., Lo, K., Ohnenstetter, D., Féménias, O., Pivin, M., Charlier, B., 2013. Petrogenesis of Archean PGM-bearing chromitites and associated ultramafic-mafic-anorthositic rocks from the Guelb el Azib layered complex (West African craton, Mauritania). Precambrian Research 224, 612-628.

Bering, D., Brinckmann, J., Camara, N., Diawara, M., Gast, L., Kieta, S., 1998. Evaluation de l'Inventaire des Resources Minerals de Guinee. In: Cooperation Technique Republique de Guinea-Republique Federal d'Allemagne, Project 94.2025.8. BGR, Hannover, p. 109.

Bessoles, B., 1977. Géologie de l'Afrique. Le craton Ouest-africain. Mémoire BRGM. no $88.402 p$.

Black, L.P., Gale, N.H., Moorbath, S., Pankhurst, R.J., McGregor, V.R., 1971. Isotopic dating of very early Precambrian amphibolite facies gneisses from the 
Godthaab district, West Greenland. Earth and Planetary Science Letters 12. 245-259.

Bonhomme M., 1962. Contribution à l'étude géochronologique de la plate- forme de l'Ouest africain. Annales de la Faculté des Sciences, Université de ClermontFerrand 5, 62p.

Cahen, L., Snelling, N.J., Delhal, J., Vail, J.R., 1984. The Geochronology and Evolution of Africa. Clarendon Press, Oxford.

Camil, J., 1984. Pétrographie, chronologie des ensembles granulitiques archéens et formations associées de la région de Man (Côte d'Ivoire). Implications pour I'histoire géologique du craton Ouest Africain. Thèse Doctorat Ès Sciences. Université Abidjan, 306p.

Deckart, K., H. Bertrand, and J.-P. Liegeois, 2005. Geochemistry and Sr, Nd, Pb isotopic composition of the Central Atlantic Magmatic Province (CAMP) in Guyana and Guinea, Lithos, 82(3), 289-314.

De Kock, G.S., Théveniaut, H., Botha, P.M.W., Gyapong, W., 2012. Timing the structural events in the Paleoproterozoic Bolé-Nangodi belt terrane and adjacent Maluwe basin, West African Craton, in central-west Ghana. Journal of Africa Earth Sciences. 65, 1-24.

De Waele, B., Lacorde, M., Vergara, F., Chan, G., 2015. New insights on Proterozoic tectonics and sedimentation along the peri-Gondwanan West African margin based upon U-Pb SHRIMP geochronology. Precambrian Research 259, 156175.

Dhuime, B., Hawkesworth, C. J., Cawood, P. A., \& Storey, C. D., 2012. A Change in the Geodynamics of Continental Growth 3 Billion Years Ago. Science 335 (6074), 1334-1336. doi:10.1126/science.1216066. 
Eberhardt, P., Geiss, J., Houtermans, F.G., Signer, P., 1962. Age determination on lead ores. Geologische Rundschau 52, 836-852.

Egal, E., Thiéblemont, D., Lahondére, D., Guerrot, C., Costea, C.A., Iliescu, D., Delor, D., Goujou, J.-C., Lafon, J.M., Tegyey, M., Diaby, S., Kolié, P., 2002. Late Eburnean granitization and tectonics along the western and northwestern margin of the Archean Kénéma-Man domain (Guinea, West African Craton). Precambrian Research.117, 57-84.

Eglinger, A., Thébaud, N., Zeh, A., Davis, J., Miller, J., Parra-Avila, L.A., Loucks, R.,McCuaig, C., Belousova, E., 2017. New insights into the crustal growth of the Paleoproterozoic margin of the Archean Kéména-Man domain, West African craton (Guinea): Implications for gold mineral system. Precambrian Res. 292, 58-289.

Ennih, N., Liégeois, J.P., 2008. The boundaries of the West African Craton, with special reference to the basement of the Moroccan metaCratonic Anti-Atlas belt. In: Ennih, N., Liégeois, J.P. (Eds.). The Boundaries of the West African Craton. The Geological Societyof London Special Publication 297, 1-17.

Feybesse, J.L., Milési, J.-P., 1994. The Archean/Paleoproterozoic contact zone in West Africa: a mountain belt of décollement thrusting and folding on a continental margin related to $2.1 \mathrm{Ga}$ convergence of Archean Cratons? Precambrian Research 69,199-227.

Feybesse, J.L., Billa, M., Guerrot, C., Duguey, E., Lescuyer, J.L., Milési, J.P., Bouchot, V., 2006. The Paleoproterozoic Ghanaian province: geodynamic model and ore controls, including regional stress modeling. Precambrian Research 149,149-196. 
Fisher, C. M., Vervoort, J. D., 2018. Using the magmatic record to constrain the growth of continental crust-The Eoarchean zircon Hf record of Greenland. Earth and Planetary Science Letters, 488, 79-91. doi:10.1016/j.epsl.2018.01.031.

Goldich, S.S., Hedge, C.E., Stern, T.W., 1970. Age of the Morton and Montevideo gneisses and related rocks, southwestern Minnesota. Geological Society of America Bulletin 81, 3671-3996.

Gouedji, F., Picard, C., Coulibaly, Y., Audet, M.-A., Auge, T., Goncalves, P., Paquette, J.L.,Ouattara, N., 2014. The samapleu maficeultramafic intrusion and its NiCuPGE mineralization: an Eburnean $(2.09 \mathrm{Ga})$ feeder dyke to the Yacouba layered complex (Man Archean craton, western Ivory Coast). Bull. Soc. Geol. Fr. 185, 393-411.

Gorman, B.E., Pearce, T.H., Birkett, T.C., 1978. On the structure of Archaean greenstone belts. Precambrian Research 6, 23-41.

Grenholm, M., Jessell, M., Thébaud, N., 2019. A geodynamic model for the Paleoproterozoic (ca. 2.27-1.96 Ga) Birimian Orogen of the southern West African Craton - Insights into an evolving accretionary-collisional orogenic system. Earth-Science Reviews. doi:10.1016/j.earscirev.2019.02.006.

Hanson, G.N., Goldich, S.S., Arth, J.G., Yardley, D.H., 1971. Age of the early Precambrian rocks of the Saganaga Lake-Nothern Light Lake area, OntarioMinnesota. Canadian Journal of Earth Sciences 8, 1110-1124.

Heimlich, R.A., Banks, P.O., 1968. Radiometric age determinations, Bighorn Mountains, Wyoming. American Journal of Science 266, 180-192.

Hirdes, W., Davis, D.W., 2002. U-Pb geochronology of Paleoproterozoic rocks in the southern part of the Kedougou-Kéniéba Inlier, Senegal. West Africa: evidence 
for diachronous accretionary development of the Eburnean Province. Precambrian Research 118, 83-99.

Hurley, P.M., Leo, G.W., White R.W., Fairbairn H.W., 1971. Liberian Age Province (about 2,700 m.y.) and Adjacent Provinces in Liberia and Sierra Leone. GSA Bulletin 82, 3483-3490.

Jahn, B.M., Glikson, A.Y., Peucat, J.J., Hickman, A.H., 1981. REE geochemistry and isotopic data of Archaean silicic volcanics and granitoids from the Pilbara Block, western Australia: implications for the early crustal evolution. Geochimca et Cosmochimca Acta 45, 1633-1652.

Kouamelan, A.N., 1996. Géochronologie et géochimie des formations archéennes et protérozoïques de la dorsale de Man en Côte d'Ivoire, implication pour la transition archéen-protérozoïque. Thèse de Doctorat Université de Rennes, France, 227p.

Kouamelan, A.N., Delor, C., Peucat, J.-J., 1997a. Geochronological evidence for reworking of Archaean terrains during the Early Proterozoic (2.1 Ga) in the western Côte d'Ivoire (Man Shield - West African Craton). Precambrian Research 86, 177-199.

Kouamelan, A.N., Peucat, J.-J., Delor, C., 1997b. Reliques archéennes (3.15 Ga) au sein du magmatisme birimien $(2.1 \mathrm{Ga})$ de Côte d'Ivoire, craton ouest-africain. Compte Rendu de l'Académie Sciences Paris 324, 719-727.

Kouamelan, A.N., Djro S.C., Allialy, M.E., Piquette J-L., Peucat J-J., 2015. The oldest rock of Ivory Coast, Journal of African Earth Sciences 103, 65-70.

Kouamelan, A. N., Kra, K. S. A., Djro, S. C., Paquette, J.-L.,Peucat, J.-J., 2018. The Logoualé Band: A large Archean crustal block in the Kenema-Man domain (Man-Leo rise, West African Craton) remobilized during Eburnean orogeny 
(2.05 Ga), Journal of African Earth Sciences, https://doi.org/10.1016/j.jafrearsci.2017.09.004.

Kouvo, O., Tilton, G.R., 1966. Mineral ages from the Finnish Precambrian. Journal of Geology 74, 421-442.

Lemoine S., 1988. Evolution géologique de la région de Dabakala (NE de la Côte d'Ivoire) au protérozoïque. Possibilités d'extension au reste de la Côte d'Ivoire et au Burkina Faso : similitudes et différences; les linéaments de GreenvilleFerkéssedougou et Grand Cess-Niakaramandougou. Thèse d'Etat, Université Clermont-Ferrand, 334p.

Ludwig K., 2008. Isoplot 4.00 beta, rev. 10 Sept, 2008. Berkeley Geochronology Centre.

MacFarlane, A., Crow, M.J., Arthurs, J.W., Wilkinson, A.F., 1980. The geology and mineral resources of northern Sierra Leone. Institute of Geological Sciences Overseas Membership. 7, 134p.

Mareschal, J.C., Jaupart, C., 2006. Archean thermal regime and stabilization of cratons. In. Benn, K., Mareschal, J.-C., Condie, K, editors, Archean geodynamics and environments, volume 164 of monographs, pages 61-73. AGU.

Martin, H., Moyen, J.-F., Guitreau, M., Blichert-Toft, J., Le Pennec, J.-L. 2014. Why Archaean TTG cannot be generated by MORB melting in subduction zones. Lithos, 198-199, 1-13. doi:10.1016/j.lithos.2014.02.017.

Montero, P., Haissen, F., El Archi, A., Rijmati, E., Bea, F., 2014. Timing of Archaean crust formation and cratonisation in the Awsard-Tichla zone of the NW Reguibat Shield, West African Craton: a SHRIMP, Nd-Sr isotopes and geochemical reconnaissance study. Precambrian Research. 242, 112-137. 
Moorbath, S., 1975. Evolution of Precambrian crust from strontium isotopic evidence. Nature 254, 395-398.

Moorbath, S., O'Nions, R.K., Pankhurst, R.J., Gale, N.H., McGregor, V.R., 1972. Further rubidium-strontium age determinations on the very eary Precambrian rocks of Godthaab region, West Greenland. Nature 240, 78-82.

Nelson, B. K., Depaolo, D.J., 1985. Rapid production of continental crust1.7 to 1.9 by ago: Nd isotopic evidence from the basement of North America Midcontinent. Geological Society of America Bulletin 96, 746-754.

Nisbet, E G., Cheadie, M.J., Arndt, N.T., Bickle, M. J., 1993. Constraining the temperature of the Archean mantle: a review of evidence from komatiites. Lithos 30, 291-307.

Parra-Avilla, L.A., Belousova, E., Fioentini, M.L., Baratoux, L., Davies, J., Miller, J., McCuig, T.C., 2016. Crustal evolution of the Palaeoproterozoic Birimian terranes of the Baoule-Mossi domain, southern West African Craton: U-Pb and Hf-isotope studies of detrital zircons. Precambrian Research 274, 25-60.

Parra-Avila, L.A., Kemp, A.I., Fiorentini, M.L., Belousova, E., Baratoux, L., Block, S., Jessell, M., Bruguier, O., Begg, G.C., Miller, J., Davis, J., 2017. The geochronological evolution of the Paleoproterozoic Baoulé-Mossi domain of the Southern West African Craton. Precambrian Research. 300, 127.

Parra-Avila, L. A., Belousova, E., Fiorentini, M. L., Eglinger, A., Block, S., \& Miller, J., 2018. Zircon $\mathrm{Hf}$ and O-isotope constraints on the evolution of the Paleoproterozoic Baoulé-Mossi domain of the southern West African Craton. Precambrian Research, 306, 174-188. doi:10.1016/j.precamres.2017.12.044.

Persits, F., Ahlbrandt, T., Tuttle, M., Charpentier, R., Brownfield, M., Takahashi, K., 2002. Map showing geology, oil and gas fields and geological provinces of 
Africa, ver. 2.0. USGS Open File Report 97-470A, http://pubs.usgs.gov/of/1997/ofr-97470/OF97 470A/index.html (accessed 6.7.13).

Petersson, A., Scherstén, A., Kemp, A.I.S., Kristinsdóttir, B., Kalvig, P., Annum, S., 2016. Zircon U-Pb-Hf evidence for subduction related crustal growth and reworking of Archaean crust within the Palaeoproterozoic Birimian terrane, West African Craton, SE Ghana. Precambrian Research. 275, 286-309. http://dx.doi.org/10.1016/j.precamres. 2016.01.006.

Petersson, A., Scherstén, A., Gerdes, A., 2017. Extensive reworking of Archaean crust within the Birimian terrane in Ghana as revealed by combined zircon $\mathrm{U}_{-}$ $\mathrm{Pb}$ and $\mathrm{Lu}-\mathrm{Hf}$ isotopes. Geoscience. Frontiershttp://dx.doi.org/10.1016/j.gsf.2017.02.006.

Petersson, A., Scherstén, A., Kristinsdóttir, B., Kemp, A. and Whitehouse, M., 2018. Birimian crustal growth in the West African Craton: $\mathrm{U}-\mathrm{Pb}, \mathrm{O}$ and Lu-Hf isotope constraints from detrital zircon in major rivers.Chemical Geology, 479, pp.259https://doi.org/10.1016/j.chemgeo.2018.01.021.

Peucat, J.J., Capdevila, R., Drareni, A., Mahdjoub, Y., Kahoui, M., 2005. The Eglab massif in the West African Craton (Algeria), an original segment of the Eburnean orogenic belt: petrology, geochemistry and geochronology. Precambrian Research 136 (2005) 309-352.

Peucat, J.-J., Jayananda, M., Chardon, D., Capdevila, R., Fanning, C. M., \& Paquette, J.-L., 2013. The lower crust of the Dharwar Craton, Southern India: Patchwork of Archean granulitic domains. Precambrian Research, 227, 4-28. doi:10.1016/j.precamres.2012.06.009.

Pitra, P., Kouamelan, A.N., Ballevre, M., Peucat, J.J., 2010. Palaeoproterozoic highpressure granulite overprint of the Archean continental crust: evidence for 
homogeneous crustal thickening (Man Shield, Ivory Coast). Journal of metamorphic Geology, 2010, 28, 41-58.

Potrel, A., Peucat, J.J., Fanning, M., Auvray, B., Burg, J.P., Caruba, C., 1996. 3.5 Ga old terranes in the West African Craton, Mauritania. Journal of the Geological Society, London, 153, 507-510.

Potrel, A., Peucat, J. J. and Faning C. M., 1998. Archean crustal evolution of the West African Craton: example of the Amsaga Area (Reguibat Rise). U-Pb and Sm-Nd evidence for crustal growth and recycling. Precambrian Research90, $107-117$.

Pouclet, A., Doumbia, S., Vidal, M., 2006. Geodynamic setting of the Birimian volcanism in central Ivory Coast (western Africa) and its place in the Palaeoproterozoic evolution of the Man shield. Bulletin de la Société Geologique de France 177,105-121.

Pupin, J.P., 1980. Zircon and granite petrology. Contributions to Mineralogy and Petrology. 73, 207-220. Rollinson, H., 2016. Archaean crustal evolution in West Africa: A new synthesis of the Archaean geology in Sierra Leone, Liberia, Guinea and Ivory Coast. Precambrian Research. 281, 1-12.

Rollinson, R.H, Cliff, R.A., 1982. New Rb Sr age determin- ations on the Archaean basement of eastern Sierra Leone. Precambrian Research. 17, 6372.

Rudnick, R. L., 1995. Making continental crust. Nature, 378, p. 571-577.

Savanier, D., Guille, G., Maury, R.C., Blais, S., Guillou, H., Legendre, C., Rossi, P., 2003. Geology, petrology and radiochronology of Nuku Hiva (Marquesas Island, French Polynesia). EGS - AGU - EUG Joint Assembly, Nice, France, 6 -11, April 2003, Abstract id. 1105. 
Schofield, D.J., Horstwood, M.S.A., Pitfield, P.E.J., Gillespie, M., Darbyshire, F., O’Connor, E.A., Abdouloye, T.B., 2012. Precambrian Research. 204-5, 1-11.

Sylvester, P.J., Attoh, K., 1992. Lithostratigraphy and composition of $2.1 \mathrm{Ga}$ greenstone belts of the West African Craton and their bearing on crustal evolution and the Archean-Proterozoic boundary. Journal of Geology. $100,377-392$.

Tagini B., 1971. Esquisse structurale de la Côte d'Ivoire. Essai géotectonique régionale. Thèse d’Etat Université de Lausanne. SODEMI, Bulletin. $N^{\circ} 5,302 p$.

Taylor, S.R., McLennan, S.M., 1985. The continental crust: its composition and evolution. Blackwell scientific Publications, Oxford, 312 p.

Tempier P., 1986. Le Burkinien : cycle orogénique majeur du protérozoïque inférieur en Afrique de l'Ouest. Publication occasionnelle. CIFEG, n¹0, pp. 17-23.

Thiéblemont, D., Delor, C., Cocherie, A., Lafo, J.M., Goujou, J.C., Balde, A., Bah, M., Sane, H., Fanning, C.M., 2001. A 3.5 Ga granite-gneiss basement in Guinea: further evidence for early Archaean accretion within the West African Craton. Precambrian Research, 108, 179-194.

Thiéblemont, D., Goujou, J.C., Egal, E., Cocherie, A., Delor, C., Lafon, J.M., Fanning, C.M., 2004. Archaean evolution of the Leo Shield and its Eburnean reworking. Journal of Africa Earth Sciences. 39, 97-104.

Vidal, M., Alric, G., 1994. The Paleoproterozoic (Birimian) of Haute-Comoé in the West African Craton, Ivory Coast: a transtensional back-arc basin. Precambrian Research. 65, 207-229.

Whalen, L., E. Gazel, C. Vidito, J. Puffer, M. Bizimis, W. Henika, and M. J. Caddick, 2015. Supercontinental inheritance and its influence on supercontinental 
breakup: The Central Atlantic Magmatic Province and the break up of Pangea, Geochem. Geophys. Geosyst., 16, doi:10.1002/2015GC005885.

Whitney, D.L., Evans, B.W., 2010. Abbreviations for names of rock-forming minerals. American Mineralogist 95, 185-203.

Yace I., 1984. Le précambrien de l'Afrique de l'Ouest et ses corrélations avec le Brésil Oriental. Rapport final, Publication PICG-CIFEG, n², Paris, 28p. 


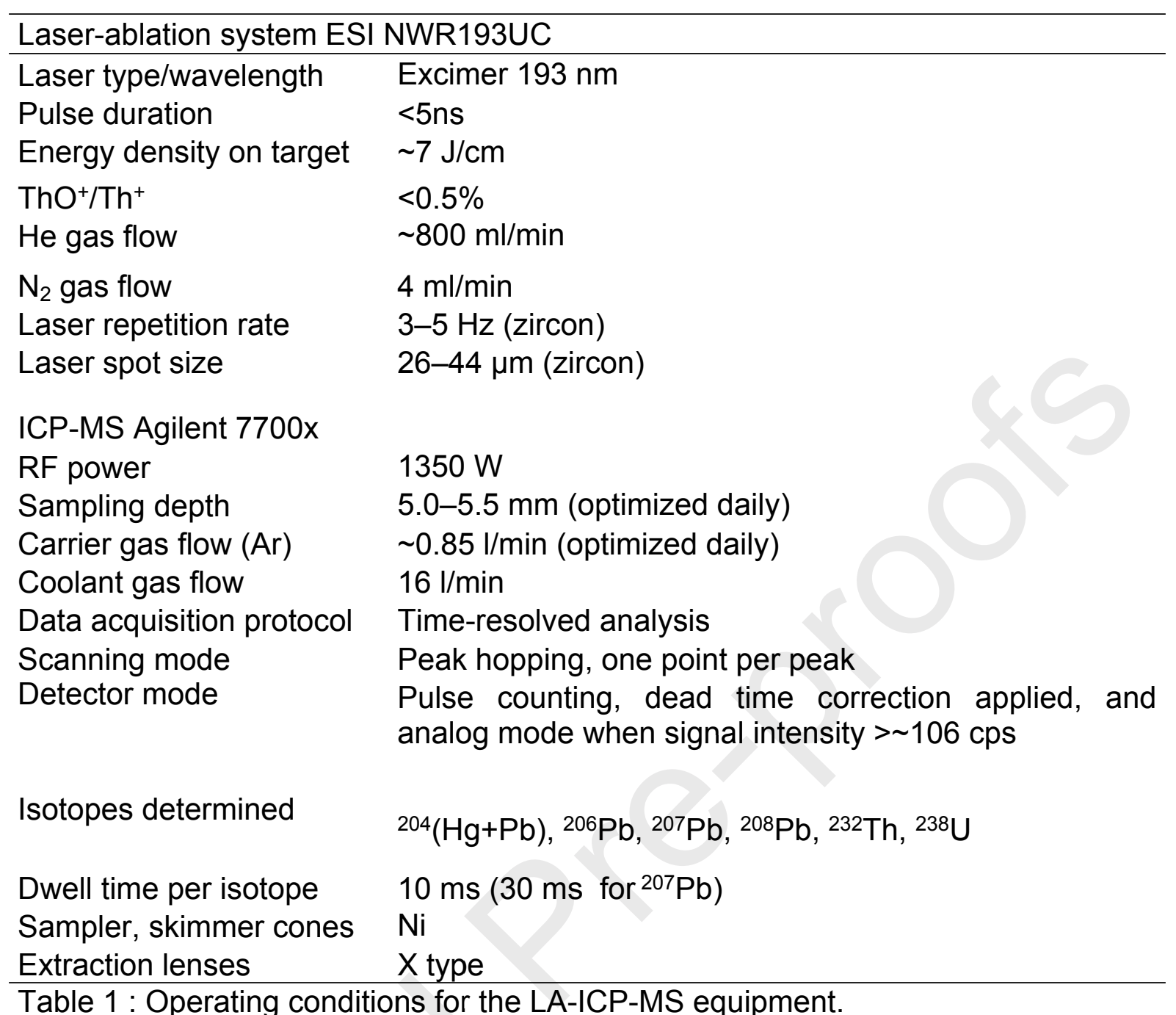




\begin{tabular}{|c|c|c|c|c|}
\hline Sample & YAL-1 & TON-1 & MANG-1 & LAG-1 \\
\hline Lat. (N) & 746'19.8" & $7^{\circ} 266^{\prime} 37.2^{\prime \prime}$ & 7³8'27.6" & 7¹4'11.7" \\
\hline Long. (W) & $7^{\circ} 33^{\prime} 42.6^{\prime \prime}$ & 7³6'53.9" & $7^{\circ} 36^{\prime} 37.8^{\prime \prime}$ & $7^{\circ} 46^{\prime} 51.3^{\prime \prime}$ \\
\hline Rock type & Granulitic grey gneiss & Granulitic grey gneiss & Charnockite & Augen orthogneiss \\
\hline $\begin{array}{l}\text { Mineral composition } \\
\text { (main accessories) }\end{array}$ & $\begin{array}{l}\text { Qz and perthitic Kf + } \\
\text { Opx, Cpx, Bt (Zircon } \\
\text { and opaques) }\end{array}$ & $\begin{array}{l}\text { Qz and perthitic Kf + } \\
\text { Opx, Cpx, biotite } \\
\text { (Zircon and opaques) }\end{array}$ & $\begin{array}{l}\text { Kf and Qz + PI, Opx, } \\
\text { Cpx. antiperthitic PI, } \\
\text { mesoperthitic Kf. } \\
\text { (Chl, Bt, zircon, } \\
\text { monazite, opaques) }\end{array}$ & $\begin{array}{l}\text { Porphyritic Qz and Kf + } \\
\text { Ferromagnesian (Hbl, } \\
\text { Bt). (Sphene, epidote, } \\
\text { zircon and apatite) }\end{array}$ \\
\hline \multicolumn{5}{|l|}{$\begin{array}{l}\text { Rock type } \\
\text { classification } \\
\text { (Barker and Arth, } \\
1976)\end{array}$} \\
\hline An-Ab-Or & Tonalitic & Tonalitic & Tonalitic & Granodioritic \\
\hline $\mathrm{K}-\mathrm{Na}-\mathrm{Ca}$ & Trondjhemitic trend & Trondjhemitic trend & Trondjhemitic trend & Calc-alkaline trend \\
\hline Structure & banded & banded & Undeformed & $\begin{array}{l}\text { Sheared, } \\
\text { foliation } \mathrm{N} 75^{\circ} \\
\text { dextral shearing } \mathrm{N} 60^{\circ}\end{array}$ \\
\hline
\end{tabular}

Table 2: Summary of main features of the studied rocks. Abbreviations after Whitney and Evans 2010. 


\begin{tabular}{|c|c|c|c|c|c|c|c|c|c|c|c|c|c|c|c|c|c|c|}
\hline \multirow{2}{*}{ Analysis } & \multirow{2}{*}{$\begin{array}{l}\text { Grain } \\
\text { Spot }\end{array}$} & \multirow{2}{*}{$\underset{(p p m)}{U}$} & \multirow{2}{*}{$\begin{array}{c}\text { Th } \\
\text { (ppm) }\end{array}$} & \multirow{2}{*}{$\begin{array}{c}\mathrm{Pb} \\
(\mathrm{ppm})\end{array}$} & \multirow{2}{*}{ Th/U } & \multicolumn{6}{|c|}{ Isotopic ratios } & \multicolumn{6}{|l|}{ Age $\mathrm{Ma}$} & \multirow[t]{2}{*}{$\begin{array}{c}\text { Conc } \\
(\%)\end{array}$} \\
\hline & & & & & & ${ }^{207} \mathrm{~Pb} / 235 \mathrm{U}$ & $\begin{array}{r} \pm 2 \sigma \\
\text { (abs) }\end{array}$ & ${ }^{206} \mathrm{~Pb} /{ }^{238} \mathrm{U}$ & $\begin{array}{r} \pm 2 \sigma \\
\text { (abs) }\end{array}$ & ${ }^{207} \mathrm{~Pb} /{ }^{206} \mathrm{~Pb}$ & $\begin{array}{l} \pm 2 \sigma \\
\text { (abs) }\end{array}$ & ${ }^{206} \mathrm{~Pb} / 238 \mathrm{U}$ & $\pm 2 \sigma$ & ${ }^{207} \mathrm{~Pb} / 235 \mathrm{U}$ & $\pm 2 \sigma$ & ${ }^{207} \mathrm{~Pb} /{ }^{206} \mathrm{~Pb}$ & $\pm 2 \sigma$ & \\
\hline \multicolumn{19}{|l|}{ YAL-1 } \\
\hline $35170614 b$ & 35 & 378 & 177 & 280 & 0.47 & 20.3625 & 0.7598 & 0.6161 & 0.0223 & 0.2397 & 0.0076 & 3094 & 89 & 3109 & 36 & 3118 & 50 & 99 \\
\hline $36170614 b$ & 36 & 264 & 96 & 187 & 0.36 & 19.6295 & 0.7301 & 0.6029 & 0.0218 & 0.2361 & 0.0074 & 3042 & 88 & 3073 & 36 & 3094 & 50 & 98 \\
\hline $37170614 b$ & 37 & 350 & 232 & 249 & 0.66 & 18.2043 & 0.6782 & 0.5726 & 0.0207 & 0.2305 & 0.0073 & 2919 & 85 & 3001 & 36 & 3056 & 50 & 96 \\
\hline $38170614 b$ & 38 & 226 & 31 & 148 & 0.14 & 19.1834 & 0.7170 & 0.5917 & 0.0214 & 0.2351 & 0.0075 & 2996 & 87 & 3051 & 36 & 3087 & 50 & 97 \\
\hline $39170614 b$ & 39 & 105 & 25 & 57 & 0.24 & 13.4191 & 0.5074 & 0.4972 & 0.0180 & 0.1957 & 0.0063 & 2602 & 78 & 2710 & 36 & 2791 & 53 & 93 \\
\hline $40170614 b$ & 40 & 500 & 229 & 331 & 0.46 & 17.4744 & 0.6513 & 0.5578 & 0.0202 & 0.2272 & 0.0072 & 2857 & 83 & 2961 & 36 & 3032 & 50 & 94 \\
\hline $41170614 b$ & 41 & 256 & 78 & 180 & 0.31 & 19.9417 & 0.7452 & 0.6123 & 0.0221 & 0.2362 & 0.0075 & 3079 & 89 & 3089 & 36 & 3094 & 50 & 100 \\
\hline $42170614 b$ & 42 & 107 & 28 & 57 & 0.26 & 13.0805 & 0.5138 & 0.4785 & 0.0176 & 0.1982 & 0.0068 & 2521 & 76 & 2686 & 37 & 2812 & 56 & 90 \\
\hline $45170614 b$ & 45 & 90 & 24 & 53 & 0.27 & 14.5595 & 0.5544 & 0.5335 & 0.0194 & 0.1979 & 0.0065 & 2756 & 81 & 2787 & 36 & 2809 & 53 & 98 \\
\hline $46170614 b$ & 46 & 136 & 37 & 71 & 0.27 & 12.5343 & 0.4743 & 0.4808 & 0.0174 & 0.1891 & 0.0061 & 2531 & 76 & 2645 & 36 & 2734 & 53 & 93 \\
\hline $47170614 b$ & 47 & 203 & 90 & 144 & 0.44 & 19.6448 & 0.7410 & 0.5999 & 0.0217 & 0.2375 & 0.0076 & 3029 & 88 & 3074 & 36 & 3103 & 51 & 98 \\
\hline $48170614 b$ & 48 & 406 & 140 & 272 & 0.34 & 18.4399 & 0.6938 & 0.5768 & 0.0209 & 0.2318 & 0.0074 & 2936 & 85 & 3013 & 36 & 3065 & 51 & 96 \\
\hline $49170614 b$ & 49 & 156 & 80 & 110 & 0.51 & 18.9790 & 0.7206 & 0.5832 & 0.0212 & 0.2360 & 0.0077 & 2962 & 86 & 3041 & 37 & 3093 & 51 & 96 \\
\hline $50170614 b$ & 50 & 82 & 80 & 57 & 0.98 & 14.7260 & 0.5625 & 0.5379 & 0.0196 & 0.1985 & 0.0065 & 2775 & 82 & 2798 & 36 & 2814 & 53 & 99 \\
\hline $51170614 b$ & 51 & 191 & 103 & 137 & 0.54 & 19.2172 & 0.7282 & 0.5959 & 0.0216 & 0.2338 & 0.0076 & 3013 & 87 & 3053 & 37 & 3079 & 51 & 98 \\
\hline $52170614 b$ & 52 & 104 & 41 & 56 & 0.40 & 12.9623 & 0.5168 & 0.4752 & 0.0175 & 0.1978 & 0.0069 & 2506 & 76 & 2677 & 38 & 2808 & 57 & 89 \\
\hline $55170614 b$ & 55 & 356 & 201 & 264 & 0.57 & 19.9911 & 0.7585 & 0.6086 & 0.0221 & 0.2382 & 0.0077 & 3065 & 88 & 3091 & 37 & 3108 & 51 & 99 \\
\hline $56170614 b$ & 56 & 214 & 42 & 133 & 0.20 & 17.9398 & 0.6864 & 0.5555 & 0.0202 & 0.2342 & 0.0077 & 2848 & 84 & 2987 & 37 & 3081 & 52 & 92 \\
\hline $57170614 b$ & 57 & 158 & 64 & 107 & 0.40 & 18.8884 & 0.7299 & 0.5752 & 0.0210 & 0.2381 & 0.0079 & 2929 & 86 & 3036 & 37 & 3108 & 53 & 94 \\
\hline $58170614 b$ & 58 & 277 & 136 & 175 & 0.49 & 16.7063 & 0.6421 & 0.5290 & 0.0193 & 0.2290 & 0.0076 & 2737 & 81 & 2918 & 37 & 3045 & 52 & 90 \\
\hline $59170614 b$ & 59 & 148 & 51 & 100 & 0.34 & 18.0724 & 0.6950 & 0.5816 & 0.0212 & 0.2253 & 0.0074 & 2955 & 86 & 2994 & 37 & 3019 & 53 & 98 \\
\hline $60170614 b$ & 60 & 113 & 49 & 70 & 0.44 & 14.7212 & 0.5760 & 0.5381 & 0.0197 & 0.1984 & 0.0067 & 2776 & 82 & 2797 & 37 & 2813 & 55 & 99 \\
\hline
\end{tabular}

Table 3: Summary of the LA-ICP-MS results for the zircons analysed in this study. 


\begin{tabular}{|c|c|c|c|c|c|c|c|c|c|c|c|c|c|c|c|c|c|c|}
\hline \multirow{2}{*}{ Analysis } & \multirow{2}{*}{$\begin{array}{l}\text { Grain } \\
\text { Spot }\end{array}$} & \multirow{2}{*}{$\underset{(p p m)}{U}$} & \multirow{2}{*}{$\begin{array}{c}\text { Th } \\
\text { (ppm) }\end{array}$} & \multirow{2}{*}{$\begin{array}{c}\mathrm{Pb} \\
(\mathrm{ppm})\end{array}$} & \multirow{2}{*}{$\mathrm{Th} / \mathrm{U}$} & \multicolumn{6}{|c|}{ Isotopic ratios } & \multirow{2}{*}{$\frac{\text { Age Ma }}{{ }^{206} \mathrm{~Pb} /{ }^{238} \mathrm{U}}$} & \multicolumn{5}{|l|}{8} & \multirow[t]{2}{*}{$\begin{array}{c}\text { Conc } \\
\%\end{array}$} \\
\hline & & & & & & ${ }^{207} \mathrm{~Pb} /{ }^{235} \mathrm{U}$ & $\begin{array}{r} \pm 2 \sigma \\
(\text { abs) }\end{array}$ & ${ }^{206} \mathrm{~Pb} /{ }^{238} \mathrm{U}$ & $\begin{array}{r} \pm 2 \sigma \\
\text { (abs) }\end{array}$ & ${ }^{207} \mathrm{~Pb} /{ }^{206} \mathrm{~Pb}$ & $\begin{array}{l} \pm 2 \sigma \\
\text { (abs) }\end{array}$ & & $\pm 2 \sigma$ & ${ }^{207} \mathrm{~Pb} /{ }^{235} \mathrm{U}$ & $\pm 2 \sigma$ & ${ }^{207} \mathrm{~Pb} /{ }^{206} \mathrm{~Pb}$ & $\pm 2 \sigma$ & \\
\hline \multicolumn{19}{|l|}{ TON-1 } \\
\hline 07170614b & 7 & 326 & 211 & 246 & 0.65 & 19.8696 & 0.7273 & 0.6106 & 0.0219 & 0.23597 & 0.0073 & 3073 & 88 & 3085 & 35 & 3093 & 49 & 99 \\
\hline 08170614b & 8 & 463 & 370 & 373 & 0.80 & 21.8213 & 0.7969 & 0.6328 & 0.0227 & 0.25007 & 0.0077 & 3161 & 90 & 3176 & 35 & 3185 & 49 & 99 \\
\hline 09170614b & 9 & 829 & 44 & 396 & 0.05 & 13.4509 & 0.4927 & 0.4418 & 0.0159 & 0.22077 & 0.0068 & 2359 & 71 & 2712 & 35 & 2986 & 50 & 79 \\
\hline $12170614 b$ & 12 & 479 & 290 & 262 & 0.60 & 12.3854 & 0.4583 & 0.4512 & 0.0163 & 0.19907 & 0.0063 & 2400 & 72 & 2634 & 35 & 2819 & 51 & 85 \\
\hline $15170614 b$ & 15 & 3334 & 400 & 1816 & 0.12 & 13.6721 & 0.4996 & 0.5079 & 0.0182 & 0.1952 & 0.006 & 2648 & 78 & 2727 & 35 & 2787 & 50 & 95 \\
\hline $16170614 b$ & 16 & 2399 & 206 & 972 & 0.09 & 9.7081 & 0.3554 & 0.3844 & 0.0138 & 0.18312 & 0.0057 & 2097 & 64 & 2408 & 34 & 2681 & 51 & 78 \\
\hline $17170614 b$ & 17 & 1035 & 477 & 686 & 0.46 & 18.0660 & 0.6611 & 0.5590 & 0.0201 & 0.23434 & 0.0073 & 2863 & 83 & 2993 & 35 & 3082 & 49 & 93 \\
\hline 18170614b & 18 & 721 & 619 & 587 & 0.86 & 21.1037 & 0.7733 & 0.6257 & 0.0225 & 0.24459 & 0.0076 & 3132 & 89 & 3143 & 36 & 3150 & 49 & 99 \\
\hline 19170614b & 19 & 424 & 263 & 280 & 0.62 & 15.0684 & 0.5540 & 0.5468 & 0.0197 & 0.19982 & 0.0062 & 2812 & 82 & 2820 & 35 & 2825 & 51 & 100 \\
\hline $20170614 b$ & 20 & 397 & 148 & 289 & 0.37 & 20.8790 & 0.7684 & 0.6185 & 0.0223 & 0.24481 & 0.0076 & 3104 & 89 & 3133 & 36 & 3152 & 49 & 98 \\
\hline $22170614 b$ & 22 & 700 & 537 & 553 & 0.77 & 20.6748 & 0.7606 & 0.6183 & 0.0223 & 0.24248 & 0.0076 & 3103 & 89 & 3124 & 36 & 3136 & 49 & 99 \\
\hline $25170614 b$ & 25 & 1775 & 157 & 813 & 0.09 & 11.2054 & 0.4126 & 0.4352 & 0.0157 & 0.18671 & 0.0058 & 2329 & 70 & 2540 & 34 & 2713 & 51 & 86 \\
\hline $28170614 b$ & 28 & 554 & 244 & 367 & 0.44 & 17.9088 & 0.6620 & 0.5531 & 0.0200 & 0.23479 & 0.0074 & 2838 & 83 & 2985 & 36 & 3085 & 50 & 92 \\
\hline $29170614 b$ & 29 & 1364 & 1388 & 1025 & 1.02 & 18.2743 & 0.6739 & 0.5680 & 0.0205 & 0.23329 & 0.0073 & 2900 & 84 & 3004 & 35 & 3075 & 50 & 94 \\
\hline $30170614 b$ & 30 & 423 & 133 & 262 & 0.31 & 14.8736 & 0.5500 & 0.5457 & 0.0197 & 0.19765 & 0.0062 & 2807 & 82 & 2807 & 35 & 2807 & 51 & 100 \\
\hline $31170614 b$ & 31 & 166 & 67 & 102 & 0.41 & 14.3406 & 0.5351 & 0.5261 & 0.0190 & 0.19766 & 0.0063 & 2725 & 80 & 2773 & 35 & 2807 & 52 & 97 \\
\hline
\end{tabular}

Table 3 : (Continued) 


\begin{tabular}{|c|c|c|c|c|c|c|c|c|c|c|c|c|c|c|c|c|c|c|}
\hline \multirow[b]{2}{*}{ Analysis } & \multirow[b]{2}{*}{$\begin{array}{l}\text { Grain } \\
\text { Spot }\end{array}$} & \multirow[b]{2}{*}{$\underset{(p p m)}{U}$} & \multirow[b]{2}{*}{$\begin{array}{c}\text { Th } \\
\text { (ppm) }\end{array}$} & \multirow[b]{2}{*}{$\underset{(\mathrm{ppm})}{\mathrm{Pb}}$} & \multirow[b]{2}{*}{$\mathrm{Th} / \mathrm{U}$} & \multicolumn{6}{|c|}{ Isotopic ratios } & \multicolumn{6}{|c|}{ Age $\mathrm{Ma}$} & \multirow[b]{2}{*}{$\begin{array}{c}\text { Conc } \\
(\%)\end{array}$} \\
\hline & & & & & & ${ }^{207} \mathrm{~Pb} / 235 \mathrm{U}$ & $\begin{array}{r} \pm 2 \sigma \\
\text { (abs) }\end{array}$ & ${ }^{206} \mathrm{~Pb} / 238 \mathrm{U}$ & $\begin{array}{r} \pm 2 \sigma \\
\text { (abs) }\end{array}$ & ${ }^{207} \mathrm{~Pb} /{ }^{206} \mathrm{~Pb}$ & $\begin{array}{c} \pm 2 \sigma \\
\text { (abs) }\end{array}$ & ${ }^{206} \mathrm{~Pb} / 238 \mathrm{U}$ & $\pm 2 \sigma$ & ${ }^{207} \mathrm{~Pb} /{ }^{235} \mathrm{U}$ & $\pm 2 \sigma$ & ${ }^{207} \mathrm{~Pb} /{ }^{206} \mathrm{~Pb}$ & $\pm 2 \sigma$ & \\
\hline \multicolumn{19}{|l|}{ MANG-1 } \\
\hline 43270513 & 43 & 152 & 107 & 76 & 0.71 & 14.42489 & 0.3934 & 0.52967 & 0.013 & 0.19757 & 0.005 & 2740 & 56 & 2778 & 26 & 2806 & 40 & 98 \\
\hline 44270513 & 44 & 1239 & 189 & 361 & 0.15 & 9.04033 & 0.2448 & 0.33754 & 0.008 & 0.1943 & 0.005 & 1875 & 41 & 2342 & 25 & 2779 & 39 & 67 \\
\hline 45270513 & 45 & 27 & 18 & 14 & 0.64 & 14.33441 & 0.4101 & 0.53578 & 0.014 & 0.19409 & 0.005 & 2766 & 58 & 2772 & 27 & 2777 & 43 & 100 \\
\hline 46270513 & 46 & 122 & 81 & 62 & 0.66 & 14.56689 & 0.4072 & 0.54246 & 0.014 & 0.19481 & 0.005 & 2794 & 58 & 2787 & 27 & 2783 & 42 & 100 \\
\hline 47270513 & 47 & 153 & 100 & 78 & 0.66 & 14.70509 & 0.4047 & 0.54466 & 0.014 & 0.19586 & 0.005 & 2803 & 57 & 2796 & 26 & 2792 & 41 & 100 \\
\hline 48270513 & 48 & 124 & 70 & 63 & 0.57 & 14.92693 & 0.4134 & 0.55019 & 0.014 & 0.19682 & 0.005 & 2826 & 58 & 2811 & 26 & 2800 & 41 & 101 \\
\hline 49270513 & 49 & 64 & 55 & 34 & 0.85 & 15.06598 & 0.4252 & 0.53916 & 0.014 & 0.20272 & 0.005 & 2780 & 58 & 2819 & 27 & 2848 & 42 & 98 \\
\hline 50270513 & 50 & 128 & 101 & 67 & 0.79 & 14.74365 & 0.4155 & 0.545 & 0.014 & 0.19626 & 0.005 & 2804 & 58 & 2799 & 27 & 2795 & 42 & 100 \\
\hline 51270513 & 51 & 93 & 97 & 52 & 1.04 & 15.34103 & 0.4692 & 0.56011 & 0.015 & 0.1987 & 0.006 & 2867 & 63 & 2837 & 29 & 2816 & 48 & 102 \\
\hline 52270513 & 52 & 280 & 121 & 136 & 0.43 & 14.55684 & 0.4024 & 0.5355 & 0.013 & 0.19721 & 0.005 & 2765 & 56 & 2787 & 26 & 2803 & 41 & 99 \\
\hline 56270513 & 56 & 273 & 162 & 141 & 0.59 & 14.83312 & 0.4155 & 0.54959 & 0.014 & 0.1958 & 0.005 & 2824 & 57 & 2805 & 27 & 2792 & 42 & 101 \\
\hline 57270513 & 57 & 20 & 12 & 10 & 0.59 & 14.88061 & 0.4387 & 0.54781 & 0.014 & 0.19707 & 0.006 & 2816 & 60 & 2808 & 28 & 2802 & 45 & 100 \\
\hline 58270513 & 58 & 222 & 195 & 117 & 0.88 & 14.57528 & 0.4108 & 0.53121 & 0.013 & 0.19905 & 0.005 & 2747 & 56 & 2788 & 27 & 2818 & 42 & 97 \\
\hline 59270513 & 59 & 225 & 72 & 106 & 0.32 & 14.40554 & 0.4073 & 0.53304 & 0.013 & 0.19606 & 0.005 & 2754 & 56 & 2777 & 27 & 2794 & 42 & 99 \\
\hline 60270513 & 60 & 334 & 160 & 167 & 0.48 & 14.79171 & 0.4183 & 0.54871 & 0.014 & 0.19557 & 0.005 & 2820 & 57 & 2802 & 27 & 2790 & 42 & 101 \\
\hline 61270513 & 61 & 108 & 77 & 57 & 0.71 & 14.95637 & 0.4288 & 0.54958 & 0.014 & 0.19743 & 0.005 & 2823 & 58 & 2813 & 27 & 2805 & 43 & 101 \\
\hline 62270513 & 62 & 22 & 12 & 11 & 0.55 & 14.93738 & 0.4371 & 0.54819 & 0.014 & 0.19768 & 0.005 & 2818 & 59 & 2811 & 28 & 2807 & 45 & 100 \\
\hline 63270513 & 63 & 63 & 68 & 35 & 1.07 & 14.35555 & 0.4143 & 0.54166 & 0.014 & 0.19227 & 0.005 & 2790 & 57 & 2774 & 27 & 2762 & 44 & 101 \\
\hline 64270513 & 64 & 119 & 49 & 59 & 0.41 & 14.81777 & 0.4306 & 0.54275 & 0.014 & 0.19806 & 0.005 & 2795 & 58 & 2804 & 28 & 2810 & 44 & 99 \\
\hline 65270513 & 65 & 112 & 71 & 59 & 0.63 & 14.98229 & 0.4317 & 0.55108 & 0.014 & 0.19724 & 0.005 & 2830 & 58 & 2814 & 27 & 2804 & 44 & 101 \\
\hline 66270513 & 66 & 155 & 102 & 81 & 0.66 & 14.95356 & 0.4316 & 0.54881 & 0.014 & 0.19767 & 0.005 & 2820 & 58 & 2812 & 27 & 2807 & 44 & 100 \\
\hline 67270513 & 67 & 76 & 56 & 40 & 0.73 & 14.57393 & 0.4258 & 0.54196 & 0.014 & 0.19509 & 0.005 & 2792 & 58 & 2788 & 28 & 2786 & 45 & 100 \\
\hline 4270513 & 4 & 63 & 62 & 36 & 0.58 & 15.22572 & 0.4005 & 0.55899 & 0.014 & 0.19757 & 0.005 & 2863 & 57 & 2830 & 25 & 2806 & 38 & 101 \\
\hline 5270513 & 5 & 18 & 11 & 10 & 0.91 & 15.05397 & 0.4099 & 0.55783 & 0.014 & 0.19575 & 0.004 & 2858 & 59 & 2819 & 26 & 2791 & 40 & 101 \\
\hline 6270513 & 6 & 206 & 109 & 106 & 0.98 & 15.01524 & 0.3938 & 0.55764 & 0.014 & 0.19531 & 0.005 & 2857 & 57 & 2816 & 25 & 2787 & 38 & 101 \\
\hline 7270513 & 7 & 182 & 105 & 95 & 0.91 & 15.15258 & 0.3991 & 0.56139 & 0.014 & 0.19578 & 0.006 & 2872 & 57 & 2825 & 25 & 2791 & 38 & 101 \\
\hline
\end{tabular}

Table 3 : (Continued) 


\begin{tabular}{|c|c|c|c|c|c|c|c|c|c|c|c|c|c|c|c|c|c|c|}
\hline \multirow[b]{2}{*}{ Analysis } & \multirow[b]{2}{*}{$\begin{array}{l}\text { Grain } \\
\text { Spot }\end{array}$} & \multirow[b]{2}{*}{$\underset{(p p m)}{U}$} & \multirow[b]{2}{*}{$\begin{array}{c}\text { Th } \\
\text { (ppm) }\end{array}$} & \multirow[b]{2}{*}{$\begin{array}{c}\mathrm{Pb} \\
(\mathrm{ppm})\end{array}$} & \multirow[b]{2}{*}{ Th/U } & \multicolumn{6}{|c|}{ Isotopic ratios } & \multicolumn{6}{|c|}{ Age $\mathrm{Ma}$} & \multirow[b]{2}{*}{$\begin{array}{c}\text { Conc } \\
(\%)\end{array}$} \\
\hline & & & & & & ${ }^{207} \mathrm{~Pb} / 235 \mathrm{U}$ & $\begin{array}{r} \pm 2 \sigma \\
\text { (abs) }\end{array}$ & ${ }^{206} \mathrm{~Pb} / 238 \mathrm{U}$ & $\begin{array}{r} \pm 2 \sigma \\
\text { (abs) }\end{array}$ & ${ }^{207} \mathrm{~Pb} /{ }^{206} \mathrm{~Pb}$ & $\begin{array}{l} \pm 2 \sigma \\
\text { (abs) }\end{array}$ & ${ }^{206} \mathrm{~Pb} / 238 \mathrm{U}$ & $\pm 2 \sigma$ & ${ }^{207} \mathrm{~Pb} / 235 \mathrm{U}$ & $\pm 2 \sigma$ & ${ }^{207} \mathrm{~Pb} /{ }^{206} \mathrm{~Pb}$ & $\pm 2 \sigma$ & \\
\hline LAG-1 & & & & & & & & & & & & & $\theta$ & & & & & \\
\hline 11270513 & 11 & 161 & 44 & 75 & 0.27 & 14.6024 & 0.3796 & 0.5363 & 0.0134 & 0.1975 & 0.0044 & 2768.1000 & 56.380 & 2790 & 25 & 2806 & 36 & 99 \\
\hline 12270513 & 12 & 128 & 42 & 60 & 0.33 & 14.4018 & 0.3758 & 0.5365 & 0.0135 & 0.1947 & 0.0044 & 2768.7000 & 56.500 & 2777 & 25 & 2783 & 37 & 100 \\
\hline 13270513 & 13 & 78 & 84 & 42 & 1.08 & 14.4516 & 0.3784 & 0.5308 & 0.0134 & 0.1975 & 0.0045 & 2744.8000 & 56.220 & 2780 & 25 & 2806 & 37 & 98 \\
\hline 17270513 & 17 & 62 & 65 & 34 & 1.05 & 14.6691 & 0.3935 & 0.5366 & 0.0137 & 0.1983 & 0.0047 & 2769.4000 & 57.460 & 2794 & 26 & 2812 & 39 & 98 \\
\hline 19270513 & 19 & 74 & 90 & 42 & 1.21 & 15.0259 & 0.3984 & 0.5488 & 0.0139 & 0.1986 & 0.0046 & 2820.2000 & 57.740 & 2817 & 25 & 2815 & 38 & 100 \\
\hline 20270513 & 20 & 125 & 114 & 68 & 0.91 & 15.1010 & 0.3994 & 0.5491 & 0.0138 & 0.1995 & 0.0046 & 2821.2000 & 57.640 & 2822 & 25 & 2822 & 38 & 100 \\
\hline 21270513 & 21 & 133 & 93 & 69 & 0.70 & 14.4641 & 0.3853 & 0.5449 & 0.0138 & 0.1926 & 0.0045 & 2803.7000 & 57.560 & 2781 & 25 & 2764 & 38 & 101 \\
\hline 22270513 & 22 & 178 & 122 & 88 & 0.69 & 13.7143 & 0.3622 & 0.4985 & 0.0125 & 0.1996 & 0.0046 & 2607.3000 & 53.940 & 2730 & 25 & 2823 & 37 & 92 \\
\hline 23270513 & 23 & 212 & 158 & 103 & 0.74 & 13.7103 & 0.3597 & 0.4999 & 0.0125 & 0.1990 & 0.0045 & 2613.4000 & 53.740 & 2730 & 25 & 2818 & 37 & 93 \\
\hline 24270513 & 24 & 144 & 34 & 66 & 0.24 & 14.3564 & 0.3771 & 0.5342 & 0.0134 & 0.1950 & 0.0045 & 2759.0000 & 56.140 & 2774 & 25 & 2785 & 37 & 99 \\
\hline 25270513 & 25 & 81 & 82 & 44 & 1.01 & 14.6359 & 0.3967 & 0.5473 & 0.0140 & 0.1940 & 0.0047 & 2813.9000 & 58.240 & 2792 & 26 & 2776 & 39 & 101 \\
\hline 26270513 & 26 & 138 & 129 & 71 & 0.94 & 14.1738 & 0.3844 & 0.5200 & 0.0133 & 0.1977 & 0.0048 & 2699.2000 & 56.340 & 2761 & 26 & 2808 & 39 & 96 \\
\hline 31270513 & 31 & 92 & 60 & 47 & 0.66 & 14.7288 & 0.3931 & 0.5412 & 0.0136 & 0.1974 & 0.0047 & 2788.5000 & 56.880 & 2798 & 25 & 2805 & 38 & 99 \\
\hline 32270513 & 32 & 185 & 173 & 99 & 0.93 & 14.8879 & 0.3980 & 0.5409 & 0.0136 & 0.1997 & 0.0047 & 2787.2000 & 56.860 & 2808 & 25 & 2824 & 38 & 99 \\
\hline 33270513 & 33 & 86 & 88 & 46 & 1.02 & 14.2067 & 0.3837 & 0.5189 & 0.0131 & 0.1986 & 0.0048 & 2694.4000 & 55.680 & 2764 & 26 & 2815 & 39 & 96 \\
\hline 34270513 & 34 & 367 & 28 & 145 & 0.08 & 12.1144 & 0.3223 & 0.4425 & 0.0111 & 0.1986 & 0.0047 & 2362.0000 & 49.400 & 2613 & 25 & 2815 & 38 & 84 \\
\hline 35270513 & 35 & 136 & 37 & 63 & 0.27 & 14.2583 & 0.3811 & 0.5373 & 0.0134 & 0.1925 & 0.0046 & 2772.1000 & 56.380 & 2767 & 25 & 2764 & 39 & 100 \\
\hline 36270513 & 36 & 46 & 39 & 25 & 0.85 & 15.1728 & 0.4192 & 0.5617 & 0.0144 & 0.1960 & 0.0049 & 2873.5000 & 59.380 & 2826 & 26 & 2793 & 41 & 103 \\
\hline 37270513 & 37 & 85 & 61 & 45 & 0.72 & 14.9318 & 0.4062 & 0.5535 & 0.0140 & 0.1957 & 0.0048 & 2839.5000 & 58.080 & 2811 & 26 & 2791 & 40 & 102 \\
\hline 38270513 & 38 & 138 & 43 & 65 & 0.31 & 14.6281 & 0.3946 & 0.5427 & 0.0136 & 0.1955 & 0.0047 & 2794.7000 & 56.940 & 2791 & 26 & 2789 & 39 & 100 \\
\hline 39270513 & 39 & 83 & 52 & 43 & 0.63 & 14.7877 & 0.4011 & 0.5531 & 0.0139 & 0.1939 & 0.0047 & 2838.2000 & 57.780 & 2802 & 26 & 2776 & 40 & 102 \\
\hline
\end{tabular}




\begin{tabular}{|c|c|c|c|c|c|}
\hline \multirow{2}{*}{ Sample } & \multirow{2}{*}{ Rock type } & \multirow{2}{*}{$\begin{array}{l}\text { Crystallization } \\
\text { age }\end{array}$} & \multicolumn{2}{|c|}{ Metamorphic age } & \multirow{2}{*}{$\begin{array}{c}\text { Inheritance } \\
\left({ }^{207} \mathrm{~Pb} / 206 \mathrm{~Pb}\right. \\
\text { age })\end{array}$} \\
\hline & & & Leonian & Liberian & \\
\hline YAL-1 & GGG & $3098 \pm 19 \mathrm{Ma}$ & $3019 \pm 53 \mathrm{Ma}$ & $2812 \pm 14 \mathrm{Ma}$ & \\
\hline TON-1 & GGG & $3156 \pm 24 \mathrm{Ma}$ & $3093 \pm 49 \mathrm{Ma}$ & $2806 \pm 25 \mathrm{Ma}$ & \\
\hline MANG-1 & Charnockite & $2798 \pm 8 \mathrm{Ma}$ & & & \\
\hline LAG-1 & Augen orthogneiss & $2795 \pm 12 \mathrm{Ma}$ & & & $3121 \pm 37 \mathrm{Ma}$ \\
\hline
\end{tabular}




\section{Figure captions}

Fig. 1: Geological sketch map of the West African Craton, adapted from Bessoles, 1977; Abouchami et al., 1990; Kouamelan et al., 1997; Egal et al., 2002; Persits et al., 2002; Peucat et al., 2005; Ennih and Liégeois, 2008; Pitra et al., 2010; Baratoux et al., 2011: Schofield et al., 2012. Redrawn after Berger et al., 2013.

Fig. 2: Schematic map of the Archean Man Domain in western Côte d'Ivoire with location of studied samples, adapted from Pitra et al., 2010.

Fig. 3: Concordia diagram for zircons from the YAL-1 granulitic grey gneiss sample analyzed with LA-ICP-MS, including transmitted light images of zircon grains with some ages obtained.

Fig. 4: Concordia diagram for zircons in the TON-1 granulite grey gneiss sample analyzed with LA-ICP-MS, including transmitted light images of zircon grains with some ages obtained.

Fig. 5 Concordia diagram for zircons in the Mangouion charnockite sample analyzed with LA-ICP-MS, including transmitted light images of zircon grains with some ages obtained.

Fig. 6: Concordia diagram for zircons in the Lagoulalé augen orthogneiss sample analyzed with LA-ICP-MS, including transmitted light images of zircon grains with some ages obtained.

I declare i have not any conflict of interest. 
R.-Stéphane Gnagnon KOFFI

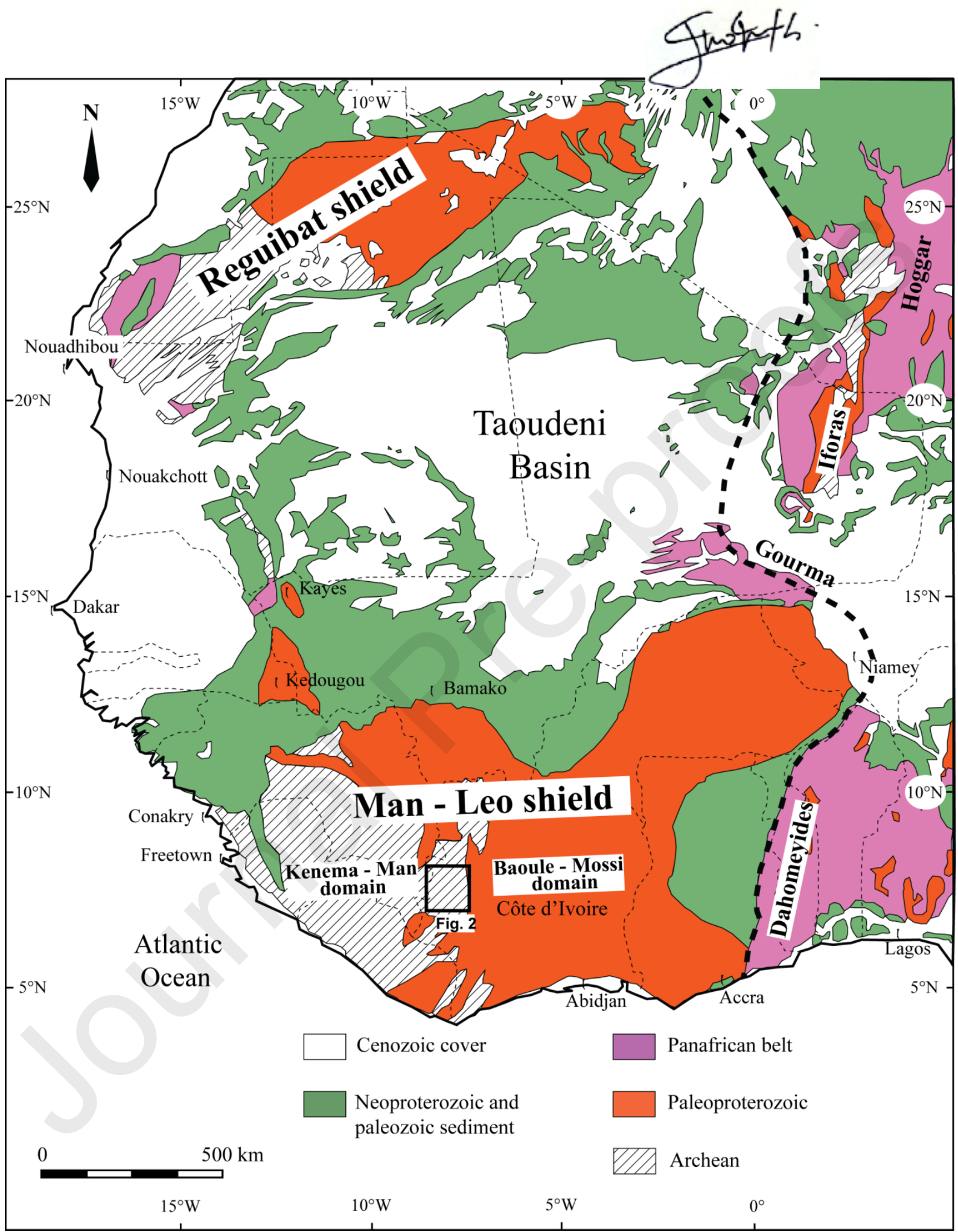




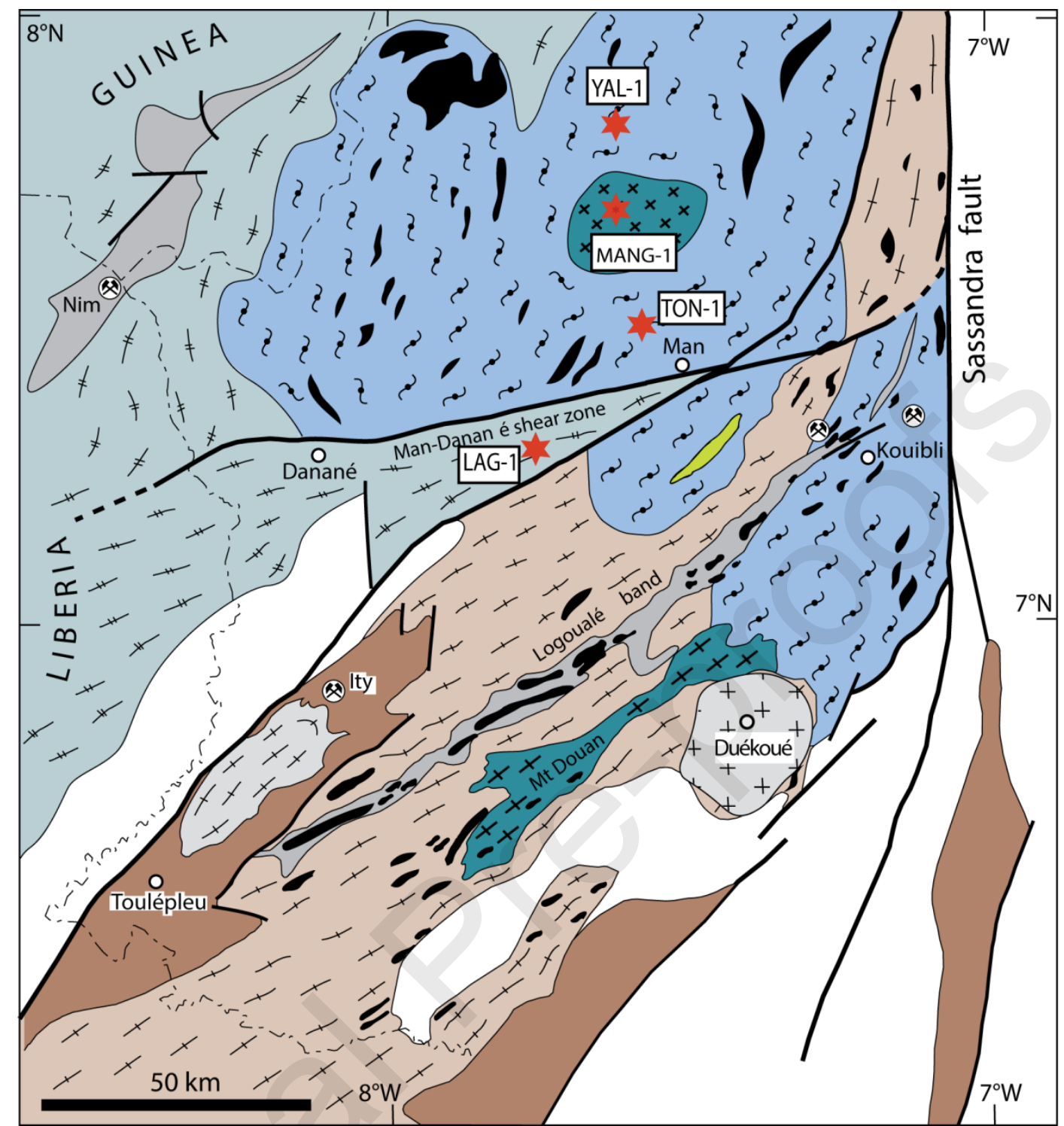

\section{Archean} opx-bearing tonalitic
gneiss / migmatite $(3.05 \mathrm{Ga}$ )

biotite migmatite / gneiss

granodioritic gneiss $(2.80 \mathrm{Ga})$

$\times x$ charnockite $(2.80 \mathrm{Ga})$

++ Duékoué granite type
Palaeoproterozoic

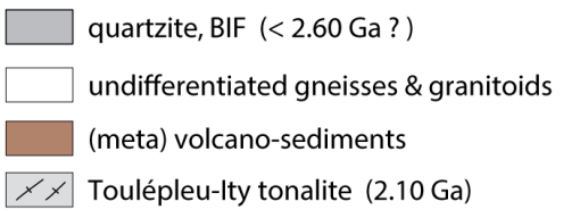

Al-rich paragneiss

metabasite

(*) ore deposit

sample location

Fig. 2. Schematic map of the Archean part of the Man Rise (the Ke 'néma-Man domain) in western Ivory Coast and location of the studied sample DANT-1, MANg-1 et LAG-1 (star). Modified after Pitra et al., 2010. 


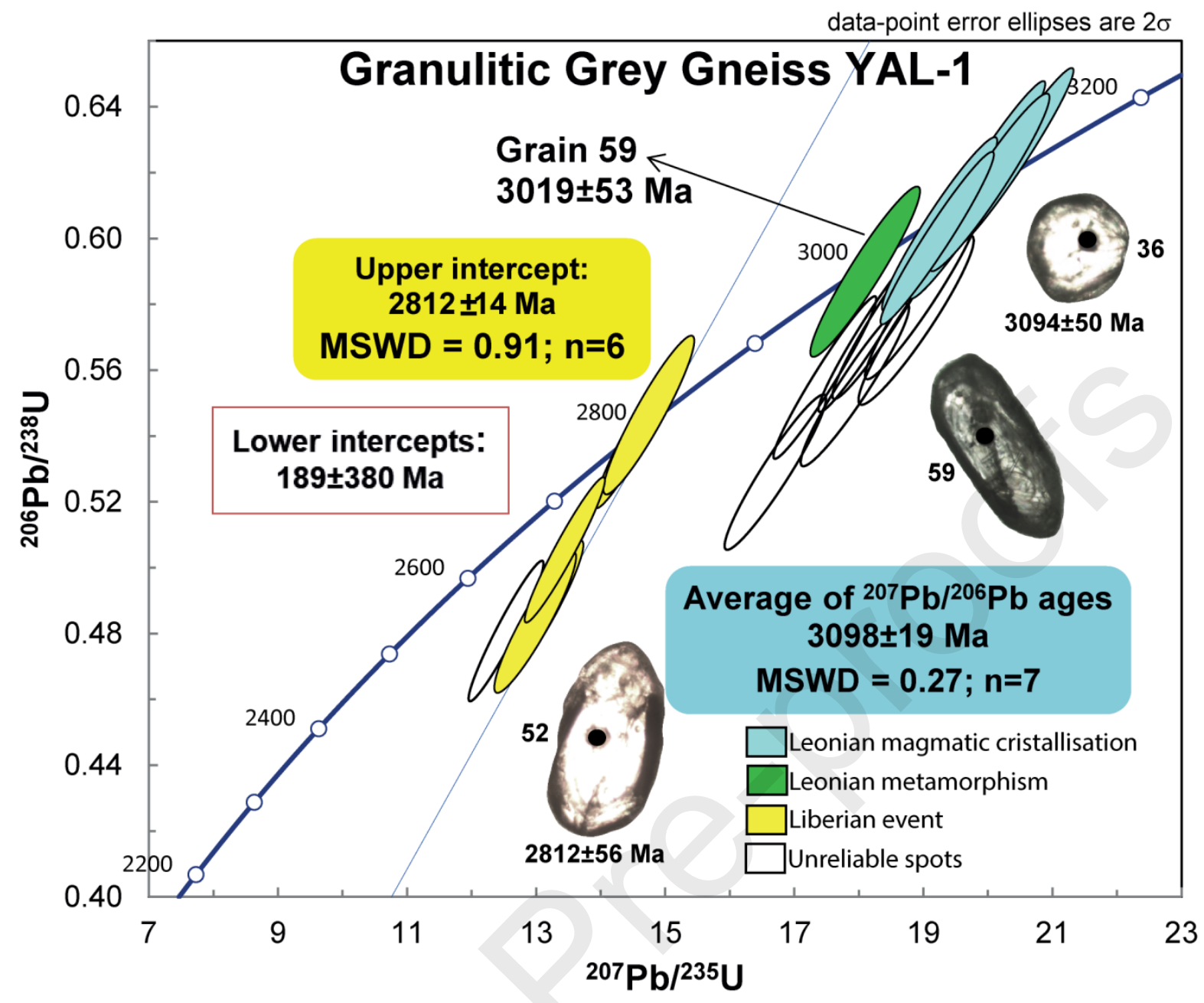




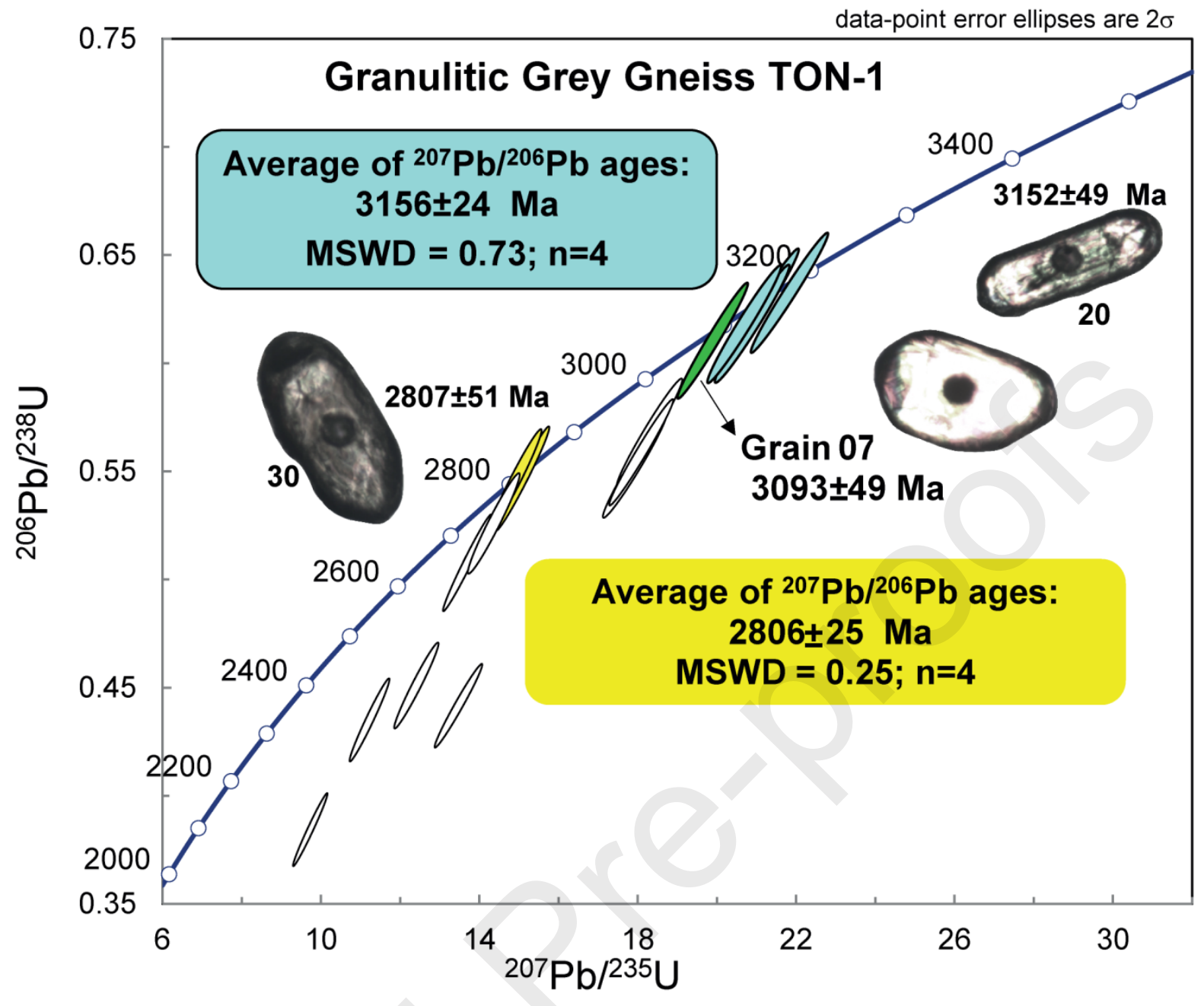




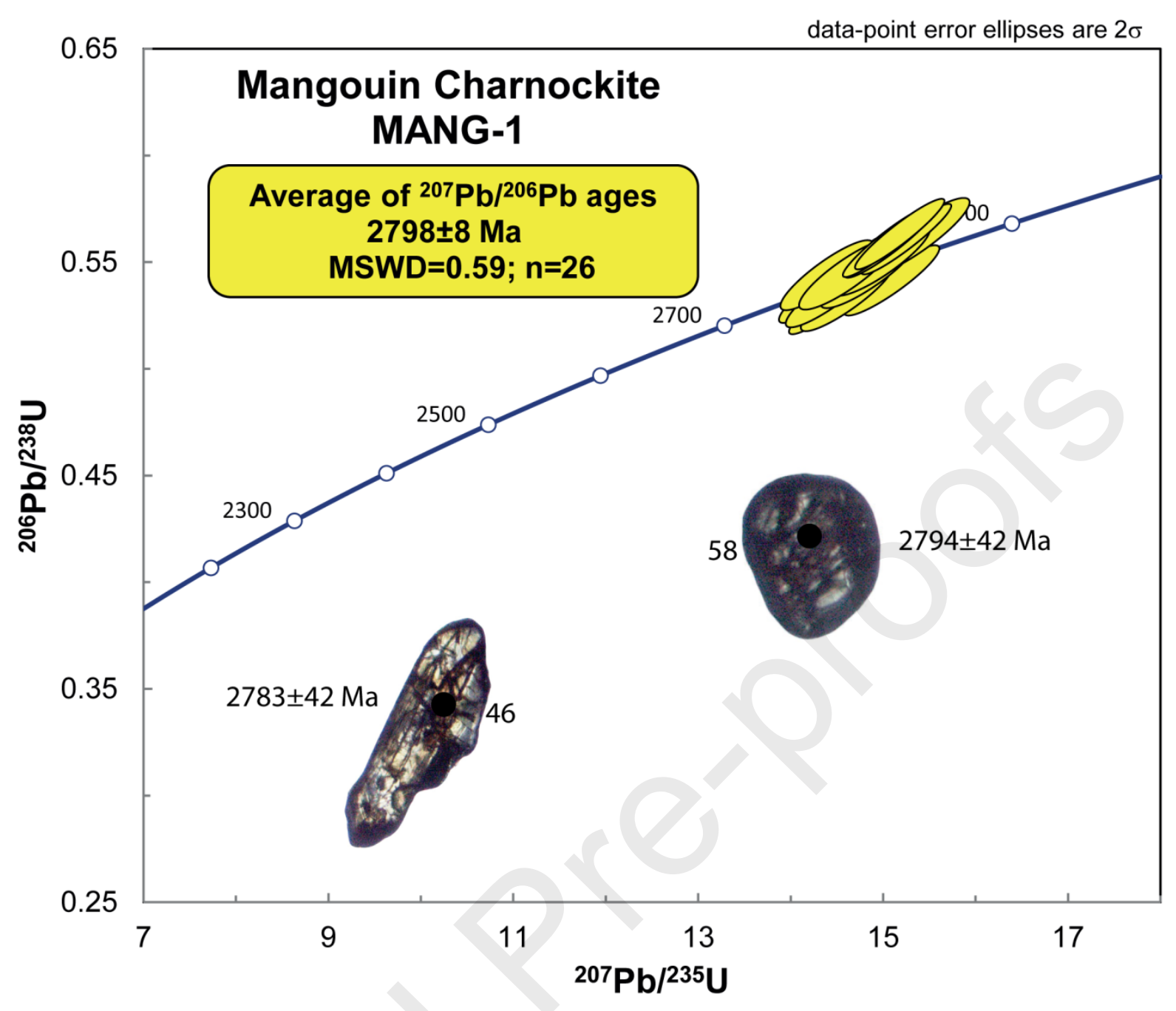




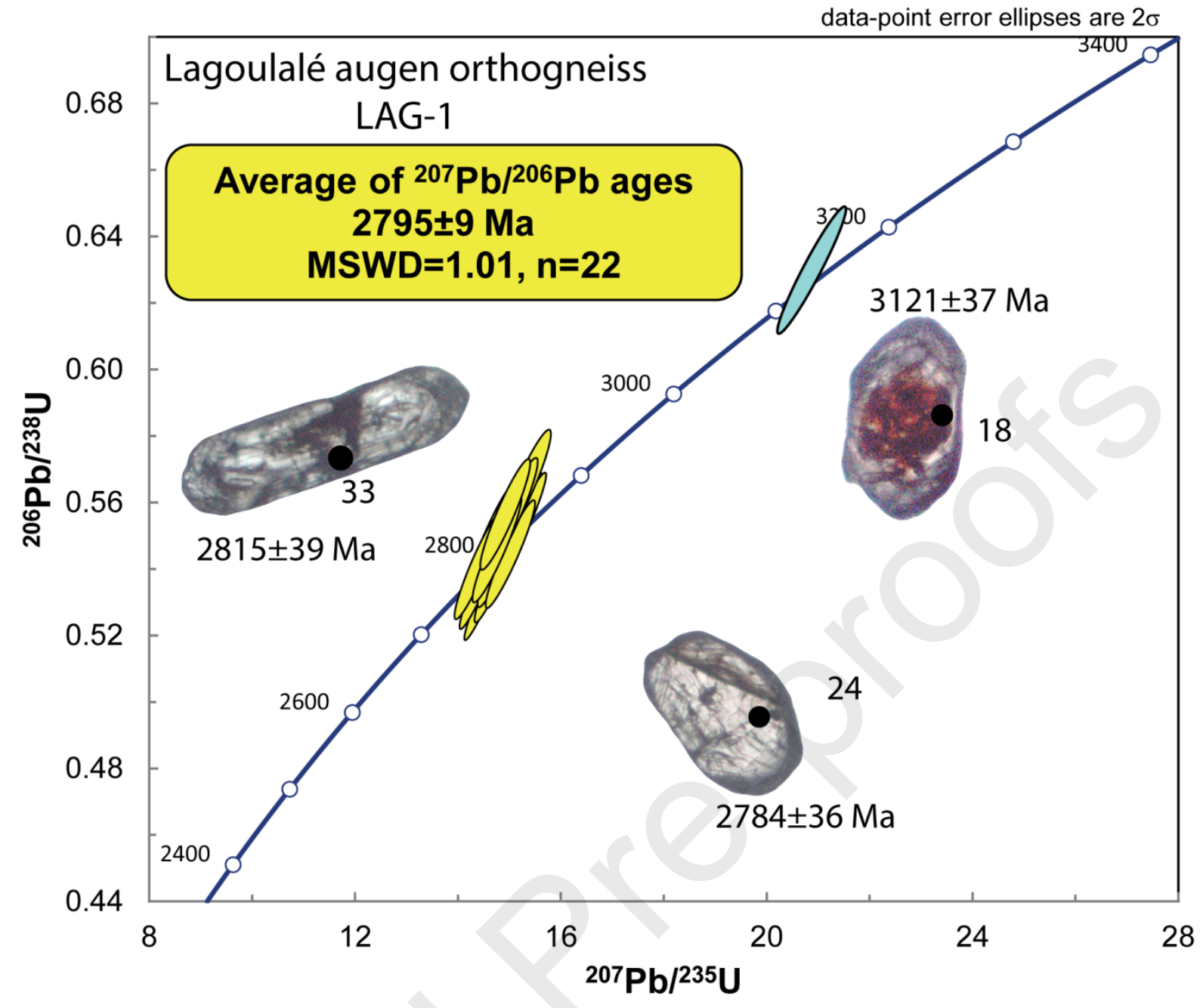




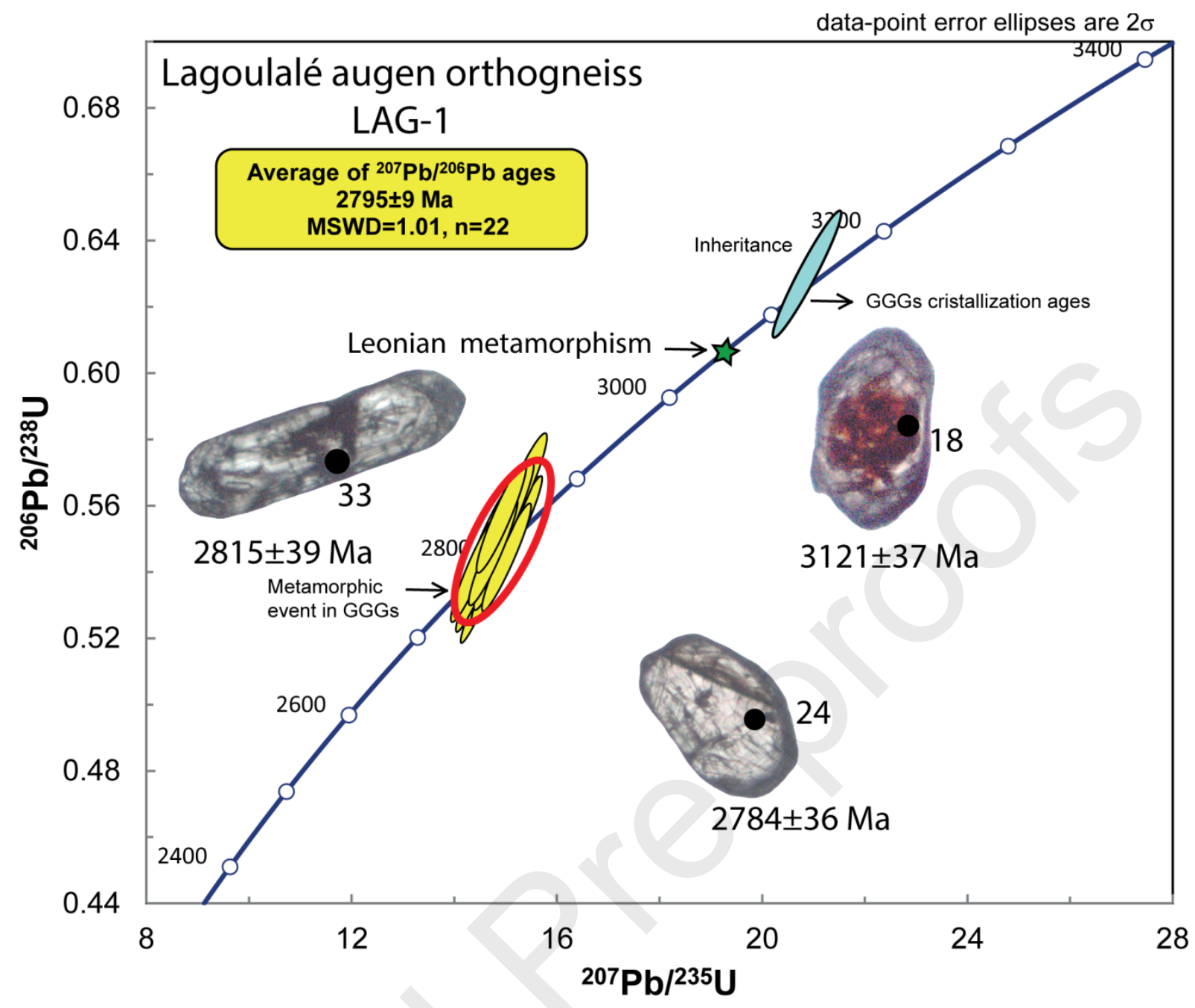

Highlights

- Leonian (3.3-3.0 Ga) and Liberian (2.9-2.7 Ga) are very distinct magmatic events.

- Leonian event has magmatism at 3.3-3.1 Ga followed by metamorphism at 3.1-3.0 Ga.

- Liberian magmatism corresponds to the reworking Leonian juvenile formations. 